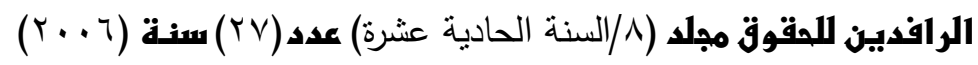

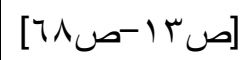

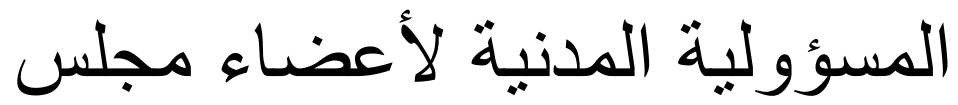

, $\cdots$

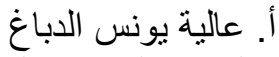

مدرس القانون التجاري المساعد العاعد

كلية القانون / جامعة الموصل الجداري
أ. أ. كامل عبد الحسين البلداوي

أستاذ القانون التجاري المساعد التيد

كلية القانون / جامعة الموصل المباعل

مقدمة:

ان أي اخلال بالتزامات اعضاء مجلس الادارة العقدية او القانونية يترتب عليه

نهوضتا المسؤولية المدنية والجزائية لتطالهم لذلك تدخل القانون في تذظيمها حماية لذوي المصالح فيسأل اعضاء مجلس الادارة في حالة مخالفة واجباتهم والحاقهم اضرارا بالشركة او بالمساهم او بالغير. لذلك اجازت القوانين اقامة الدعوى من قبل هذه الاطراف المتضررة لغرض طلب التعويض عن الضرر الذي لحق بهم من جراء اخطاء اعضاء مجلس الادارة

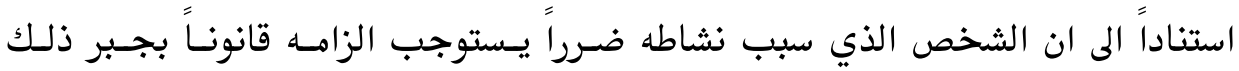
الضرر. وقد تكون هذه المسؤولية مدنية سـواء أكانـت عقديسة أم تقـصيرية ولغـرض فهـم مسؤولية اعضاء مجلس الادارة فلابد مسن بيـان المركـز القـانوني لاعـضاء مجلس الادارة ومميزات هذه المسؤولية وحالاتها .

عليه فقد ارتأينا تقسيم البحث الى مبحثين يخصص الاول منها للمركز القانوني لاعضاء مجلس الادارة ومميزات المسؤولية، ونخصص المبحث الثاني لحسالات المسؤولية المدنية.

(") بحث مستل من رسالة الماجستير الموسومة "مجلس ادارة الشركة المساهمة الخاصـة/ دراسة

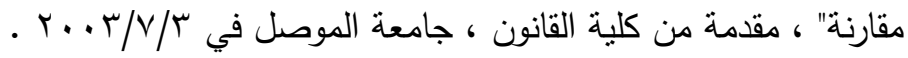




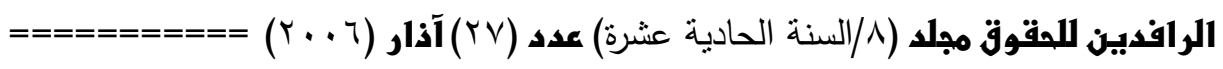

\section{الدبحــث: الأور}

المركز القانوني لأ عضاء مجلس الإدارة ومهبزات التول

\section{المسؤو لبة}

ان ارتكاب أي خطأ من قبل اعضاء مجلس الادارة يسبب ضرراً للغسير يـنهض

مسؤوليتهم المدنية والجزائية ولمسؤولية اعضاء مجلس الادارة مميزات خاصسة، وقبـل ان

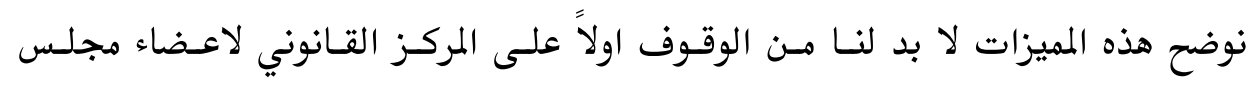
الادارة، لذا جاء هذا المبحث على مطلبين، وكالاتي:

المطلب الاول: المركز القانوني لاعضاء مجلس الادارة

المطلب الثاني: مميزات مسؤولية اعضاء مجلس الادارة

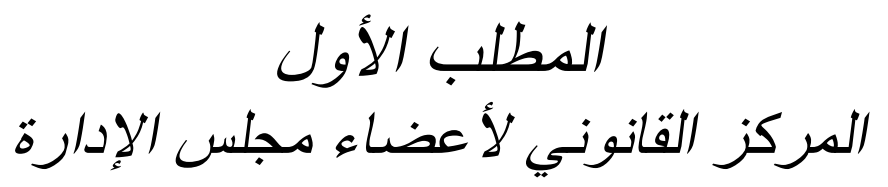

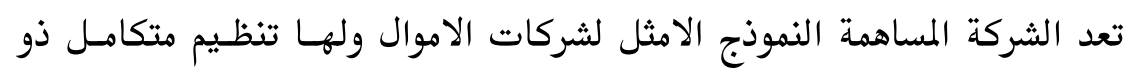
طبيعة جماعية يستقي عناصره من المفهـوم التقليسدي الـشائع لادارة الـشركات المساهمة حيث تندمج فيه المراقبـة ولا تظهر بـشكل مستقل وهـذا الـذي اعتمسدت عليـه اغلـب القوانين كالقانون العراقي والمقارن. ومسؤولية المساهمين في الشركات المساهمة المحسدودة واكثر ما يعلمونه انهم مسؤولون عن ديون الشركة بمقدار القيمة الاسمية للاسـهم كونهـا تقوم على الاعتبار المالي دون الشخصي وان اعـضاء مجلـس الادارة عـبروا عـن ارادتهـم الحرة وقبلها عليهم المساهمون ونظمها القانون فتشكل على يديهم مجلس الادارة فما هو المركز القانوني لاعضاء مجلس الادارة. 
تتنازع المركز القانوني لاعضاء مجلـس الادارة نظريتـا العقد والمنظمسة للـشركة المساهمة فيترتب على الاخذ بالنظرية التعاقدية اعتبار اعـضاء مجلس الادارة مـرتبطين بالشركة بعقد الوكالة. اما لو اخذنا بالنظرية التذظيمية (القانونية) فان مجلس الادارة لا يعتبر مرتبطا بالشركة باية رابطة عقدية بل هو مرتبط برابطـة قانونيـة بوصفه هيئسة او عضوا في الشركة لا وكيلا عنها ولما كان الاخذ باي من الذظريتين لا يمكن ان يـؤدي الى تحديد المركز القانوني لاعضاء مجلس الادارة ولايضاح العلاقة بينه وبـين الـشركة لكون طبيعة الشركة المساهمة عقدا ومنظمة فلابد من ضم الفكرتين وهذا ما سنتناوله في النقـاط الاتية :

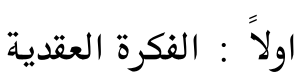
ثانياً : الفكرة القانونية : الفرد العديه ثالثاً : الفكرة التوفيقية

اولاً: الفكرة العقدية

بموجب هذه الفكرة يكون الاعتماد على اساس ان الشركة عقد وهـذا العقـد هـــ

الذي ينظم تأسيس الشركة على اساس الرضائية في نظر القانون وبموجبه يلتزم شخصان او اكثر بان يساهم كل منهم في مشروع اقتـصادي بتقـديم حسصة مسن مـال او مسن عمـل

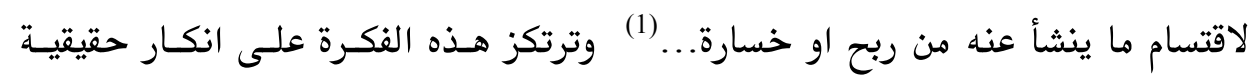
الشخص المعنوي التي ابتدعها القانون وركز على اجراءات تأسيسها م(2).

$$
\text { ( ( (1) م/ع من قانون الثركات العراقي }
$$

(r) لقد خفف القانون الفرنسي في اجراءات الترخيص عند طلب التأسيس وخفف من الثكلية د.

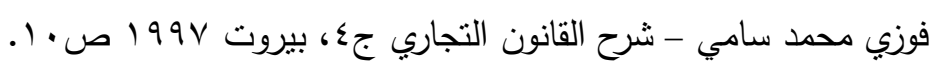




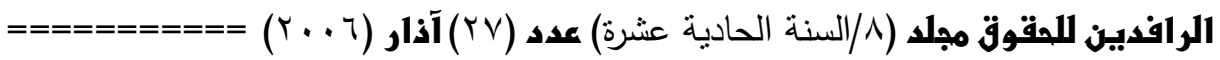

ان اصل انبثاق الفكرة العقدية جاء من مبـدأ سـلطان الارادة الـذي يمثـل احسد تطبيقات القانون الطبيعي علىى اعتبـار ان الارادة مسصدر الالتزامـات(1). واشـار القـانون العراقي صراحة الى لفظ العقد بقوله (يعد المؤسسون عقدا للشركة موقعا منهم)(2). وكذلك القانون الاردني فقد اوجب ان يرفق عقد تأسسيس الـشركة عنسد التأسسيس (3) واسـتخدم قانون الشركات الفرنسي لسنة ج719 الوكالة العقدية في اكثر من موضع وهي الراجحسة فقها وقضاء في فرنسا(4) ونصت المادة 19 من قانون التجارة الفرنسي على ان عقد الشركة يخضع لاحكام القانون المدني والقوانين الخاصة بالتجارة واتفاق الاطراف. فالشركة المساهمة تجد اساسـها في العقد على وفـق شـروطه (5) كمـا أن قـانون

الشركات الفرنسي يشير الى ادارة الشركة المساهمة بوساطة وكلاء يختارهم المساهمون (6). فالشركة حسب الفكرة العقدية لا تمثل سوى مصالح فردية وحقوق فردية وارادة

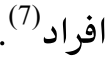

(1) محمد علي يوسف - اثز مبدأ سلطان الارادة في تكوين الثركات المساهمة - مجلة العدالة

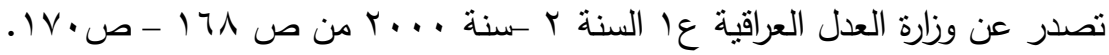

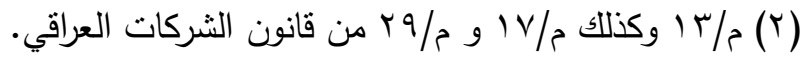

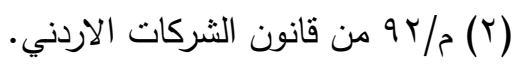

(ع) مصطفى كمال وصفي، مسؤولية مجلس الإدارة ، مصر ، 1901 ،ص بس ، ، وكذلك د. فوزي محمد سامي شرح القانون التجاري جء ،مكتبة دار الثقافة للنشر والتوزيع، عمان،

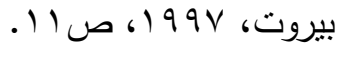

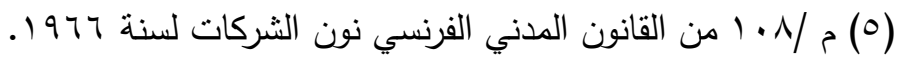
(7) م/ (7/ 1 من قانون الشركات الفرنسي. (V) د. فوزي محمد سامي، المصدر نفسه اعلاه، ص •r. 
ومن نتائج الفكرة العقدية انها تهيئ مرتكزا لتأسيس الشركة التي اساسها اتفاق

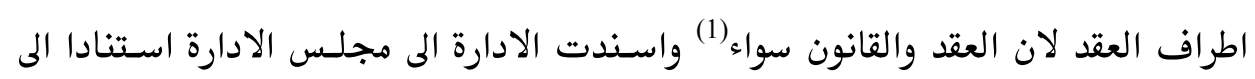
علاقة عقدية وافقت الهيئة العامة على العضوية. فما هي صفة مجلس الادارة؟ وبالذظر الى تعذر قيام جميع المساهمين الممثلين بالهيئة العامة بادارة الشركة فقد تم انتخاب عدد معين بموجب القانون يقومون نيابة عن الجميع بتأديـة مهـام اوكلتهــا

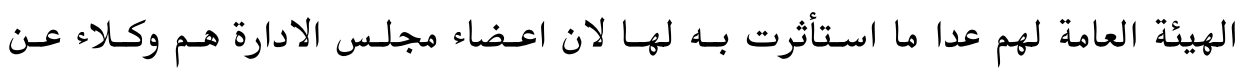
الشركة التي يتولون ادارتها وليس وكلاء عن المساهمين (2) . ان القانون العراقي لم يوضح هذه الصفة ولكن المادة هـا من قـانون الـشركات التجارية الاسبق اوضحت هذه الصفة بانه وكيل وامين(3) وان من حـق الموكـل أن يطلـق سلطة الوكيل او يقيدها على وفق القواعد العامة للوكالة ومسن حـق الموكسل ان يثبـت في الطرق كافة ان ادارة الوكيل كانت سيئة واسفرت عن الخسارة(4).

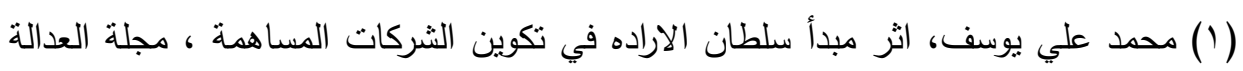

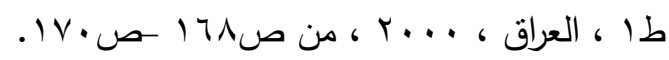

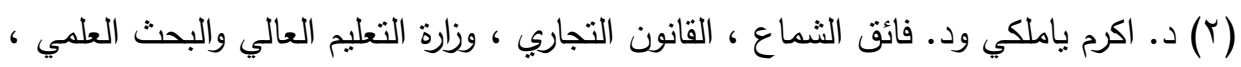

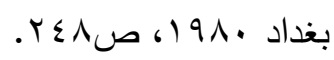
(r) ان الاستناد هذا له جذور ناريخية في القانون الانكليزي عندما كانت الثركات نتظم بعقد

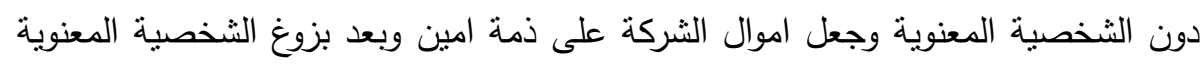

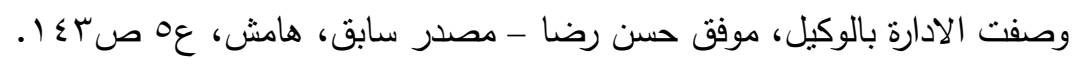

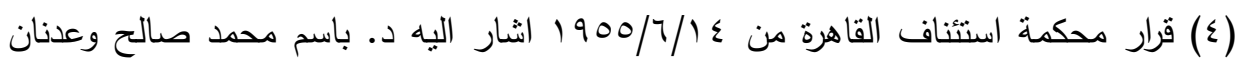

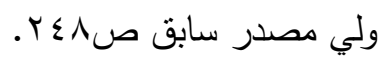




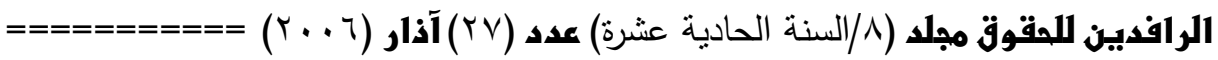

اما بعض الفقه الاردني (1) فقد عد مجلس الادارة وكيلا عـن الهيئسة العامـة امـا

القانون الفرنسي فعد اعضاء مجلس الادارة وكلاء يتم اختيارهم من المساهمين (2). ان القانون العراقي لم يوضح صفة اعـضاء مجلس الادارة في الـشركة المساهمة بالوكلاء على خلاف القوانين المقارنة ولكن اوضح بشكل صريح صفة مراقب الحسسابات بانه وكيل (3) عندما يسال عن صحة البيانات الواردة في تقريره بوصفه وكيلا عن الشركة في مراقبة حساباتها وتدقيقها فاذا طبقنا هذه الصفة على اعساء مجلس الادارة فانهمـا مطابقان من حيث التنظيم القانوني ولكن يفترقان في الاختيار. حيسث ان مسصدر اختيــار اعسضاء مجلس الادارة يـاتي بالانتخــاب مسن قبـل المساهمين والمراقب يتعين عن الهيئة العامة ولكن يمكن الاستدراك بالقول ان هناك عدداً من اعضاء مجلس الادارة منهم العاملون يمكن تمثيلهم بطريقة مخالفة للانتخـاب فاجـد ان ما يذطبق من الصفة القانونية التي صرح بها القانون العراقي على مراقب الحسسابات كونه وكيلا ينطبق على صفة اعضاء مجلس الادارة في القـانون العراقي بـانهم ذوو صفة الوكالة كذلك خاصة وان قانون الشركات التجاريسة العراقي (4) الاسسبق اشـار الى صفة التعاقدية التي تربط اعضاء مجلس الادارة بالشركة كون مسؤوليتهم وكذلك فـان مـوظفي الشركة يسألون عن اعمـالهم بمقتـضى الاحكـام القانونيـة المتعلقـة بمسؤولية الوكيـل او مسؤولية الامين.

( ) د. عزيز العكيلي، القانون التجاري ، ج ع، مكتبة دار النقافة للنشر والتوزيع،عمان،الاردن ، 1991

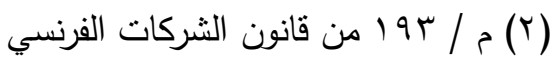

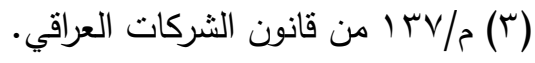
(ع) م/ 10 من قانون الثركات التجارية الاسبق. 
هذا من جهة ومن جهة اخـرى هـل ان وكالـة اعـضاء مجلـس الادارة مطابقـة للقواعد العامة في الوكالة خاصة وان موكلة مجلس الادارة شخص غير طبيعي فلا تنهض المسؤولية التقصيرية تجاهها (1). وكذلك ان سمة العقد تمثل المصالح الفرديـة والعلاقـات الشخـصية ولكـن هـذه السمة لا تذطبق على الشركة كونها تمثل مصالح غير الاشخاص الذين هم اطراف العقد كالدائنين والعاملين وحاملي السندات واقتضاء للمصلحة العامة فالقـانون وضـع نـصوصا عامة بهدف محدد لحماية هذه المصالح العامة(2) وكذلك ان الوكالة تنفـصل عـن الموكـل ولكن مجلس الادارة لا ينفصل عن الشركة وهو جزء لا يتجزأ عنها(3) وكذلك فان الوكالة

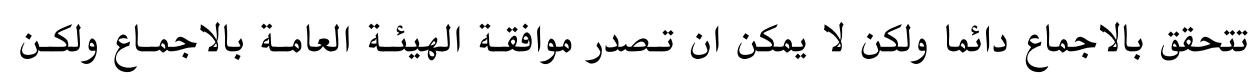
بالاغلبية غالبا.

كما انه لا يجوز للمساهم محاسبة مجلس الادارة لان عضو مجلس الادارة وكيل عن مجموع المساهمين لا عن المساهم الواحد وكذلك مهمسة المراقبـة فيستطيع الموكل ان يراقب وكيله بسهولة ويستطيع الموكل ان يرفع دعـوى الحسساب ولكن وكالـة مجلس الادارة لا يمكن ان يكون لها ذلك(4) عليه نستطيع القول ان وكالة اعضاء مجلس الادارة وكالة من نوع خاص.

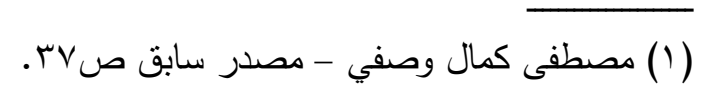

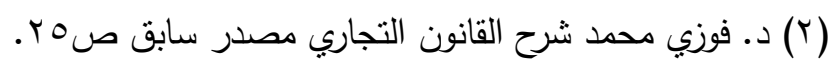

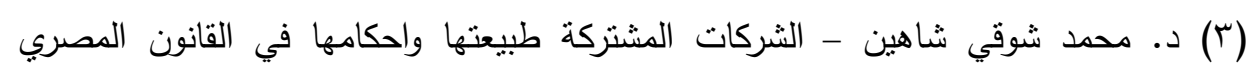

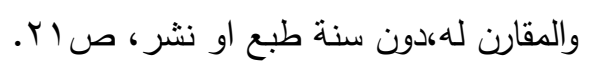

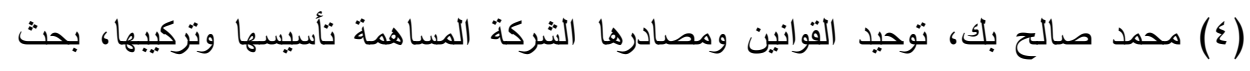

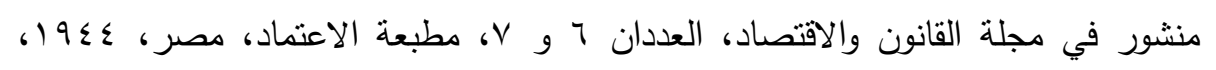

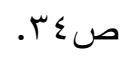




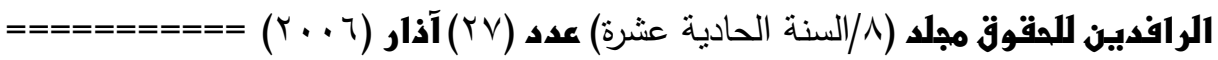

ولما ضاقت على انصار الفكرة العقدية للشركة فقد عللوا ان العقود دخل عليهـا

التطور فلم تتمسك بالتقييد خاصة عند الدعوة الى اتباع السياسة التدخلية وتقـنين فكرة حرية التعاقد عليه لابد من دراسة الفكرة القانونية وسنتناولها بالتوضيح في الفرع الآتي. ثانياً: الفكرة القانونية

لقد ضاقت الفكرة العقدية ذرعا خاصة عند الدعوة الى توفير التوازن بـين الفـرد والمجتمسع لاسـتجابة حاجـات المجتمسع لـذلك ظهـرت العقـود الموجهــة كعقد النقـل

والاذعان. وما الشركة وتنظيمها القانوني الا نصوص آمرة لحمايـة الاقتـصاد الـوطني (1). وما اكتساب الشخصية المعنوية من قبل الشركة الا خيال ومجاز وان استطاعت التملكك والتقاضي فان ذلك يعد هبة من القانون(2) وان الهيئة العامة لهـا سـلطاتها مذحهـا لهـا القانون حتى نظام العزل لمجلس الادارة في أي وقت تشاء(3). فالاختلافات الفكريسة واعستراف القـانون بالشخـصية المعنويسة للشركة بعسد ان كانت مفترضة وضربا من الخيال وبدأ التيار الفردي يضم امتداداته وبـدأت الحاجـة الى التجمعات الاقتصادية.

وبدأ يحتج بها على الغسير بعـد حـصولها على قانونيتهـا واصسح لهـا الذهـة والاهلية وحق التقاضي (4) فاصبح لهـا كـل الحقوق عـدا يكـون ملازمـا لـصفة الـشخص الطبيعي وذلك في الحدود التي يقررها القانون (1).

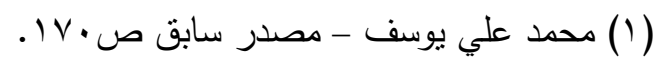
(Y) ابو زيد رضوان - مفهوم الثخصية المعنوية بين الحقيقة والخيال، بحث منشور في مجلة

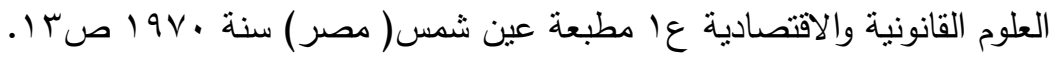

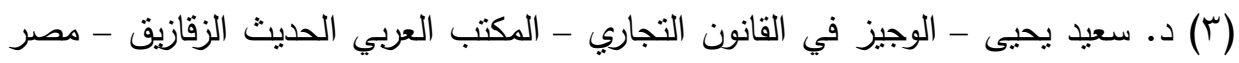
سنة .919 1 بند 1. بـ.

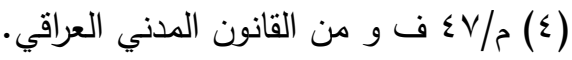


فالدستور العراقي اشار الى ان تتولى الدولة تخطيط الاقتـصاد الـوطني وتوجيهـهـ

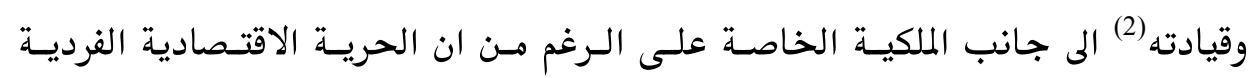
مكفولة في حدود القـانون وعلى اسـاس ان عسدم اسـتثمارها يتعـارض ويسضر بـالتخطيط الاقتصادي العام على اعتبـار ان الملكيسة وظيفـة اجتماعيسة تمـارس في حسدود واهـداف المجتمع ومناهج الدولة وفقا لاحكـام القـانون. وامـام هـذه القـوة القانونيـة والدسـتورية وتنظيم حاجات المجتمع فان تذظيم شركات الاموال يعد النموذج الامثل فتبدو هيئاتهـا كأنها مذظمة مستقلة ومنها مجلس الادارة ومحكومة بنسواميس خاصـة(3) فتلـزم الـشركة بكل التصرفات الصادرة عن مجلس الادارة الا ما هو مخالف فيعمل على المسرح القانوني بوصفه عضو مع اعضاء اخرين(4). ومجلس الادارة هو الفكـر واليسد المنفـذة لكـل اعمالهـا وان مسؤولية الـشخص المعنوي هي مسؤولية العضو ولكن بواقع قانوني منظم بما يتطلبـه نجـاح الغـرض الـذي يبغي تحقيقه وليس كواقع حسي ملمسوس وان التـصرفات الـتي يباشـرها العـضو كانمـا يباشرها الشخص المعنوي ذاته دون نيابة (5) فمجلس الادارة تجسسيد للـشركة واعـضاؤه ليسوا وكلاء عنها وانما مسؤولية الشركة شخصية ومباشرة(6).

$$
\text { (1) }
$$

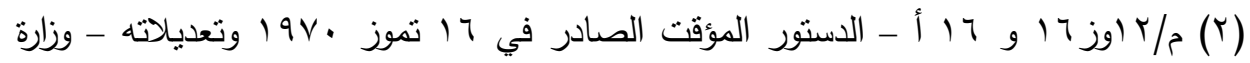

$$
\text { العدل - قسم الاعلام القانوني. }
$$

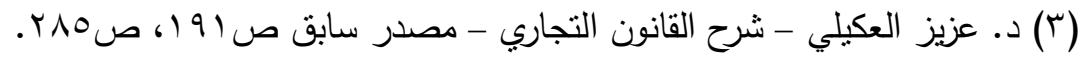

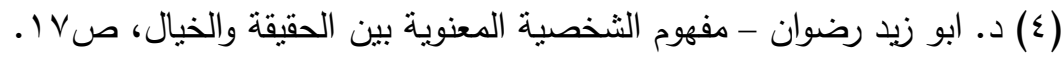

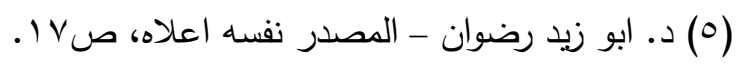

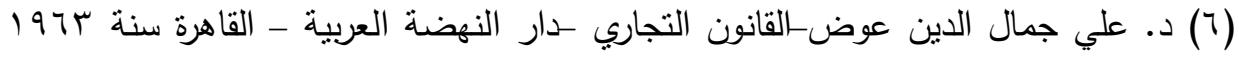

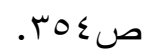




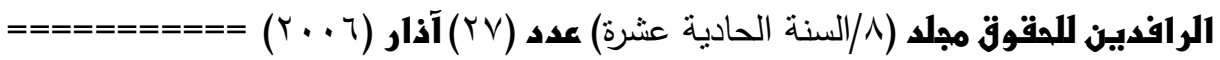

ان القانون العراقي (1) قد نص على تسمية عقد الشركة ولكن اوجب توفير جملة من البيانات التي يجب ان يتضمنها العقد فكأن العقد وثيقة بيانـات ودور القـانون دور الوصايا ومن الشواهد كذلك بانه لم يطلق الصلاحية للهيئة العامة عندما نص على ان اي غبن يتجاوز • 1\% من قيمة العقد يتصف ذلك العقد بالبطلان (2). ولقد وجدنا(3) كذلك في مرحلة التأسيس جملـة مسن الـشكليات الـتي لابـد مسن توفيرها لكي تتم الموافقة على تأسيس الشركة. عليه فان بعض الفقه (4) اشار الى ان عـضو مجلس الادارة لا يعسد مرتبطسا بـاي رابطة تعاقدية مع الشركة بل رابطة قانونية وان وكالة مجلس الادارة عسن الـشركة هي وكالة قانونية لـذا تكـون مسؤوليته تجـاه الـشركة والمساهم والغسير مسؤولية تقـصيرية والتزامات اعضاء مجلس الادارة يفرضها عليهم القانون(5). كما ان ظهور الشخص المعنوي هو احد مكنات القانون الآمرة فضلاً عن وجوب لهن الحصول على اذن حكومي لتأسيس الشركة (6) وان اعفاء أي شخص من اعضاء الـشركة

$$
\begin{aligned}
& \text { (1) م / با من قانون الشركات العراقي. }
\end{aligned}
$$

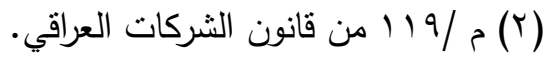

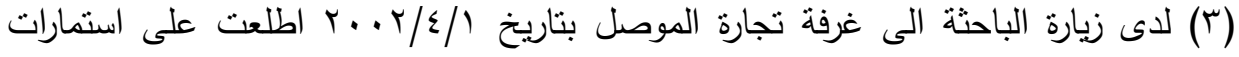

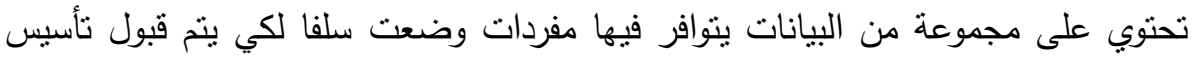

$$
\text { الثركة. }
$$

(§) د. اكرم ياملكي - الوجيز في شرح القانون التجاري العراقي ، جr ،مطبعة الناهي ، بغداد

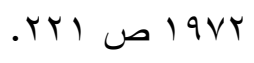

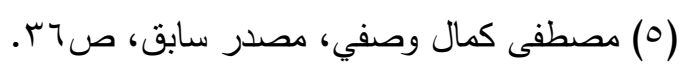

(7) عباس مرزوق فليح العبيدي، الاكتتاب في رأس مال الثركة المساهمة،مكتبة دار الثقافة

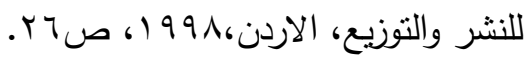


بموجب قانون خاص لا يجعلها هي معفـاة ايسضا لان شخـصيتها المعنويسة مستقلة عسن

الغير(1).

عليه فان مجلس الادارة ومن خلال مهمته التنفيذية يعتبر عضوا وليس طرفا مع

المساهم وهو وكيل عن مجموع المساهمين وليس المساهم الفرد والشركة هي التي تحاسسبه

وما التضامن ومسؤولية مجلس الادارة الا تصور واضح على عدم كفاية الفكرة العقدية وان خطأ المجلس يتحدد بموجب القواعـد العامسة للمسؤولية التقـصيرية وكـذلك الحـال في المسؤولية الجنائية ويحصل عـضو مجلس الادارة على سـلطته عـن طريسق المساهمة في المجلس اما خارج المجلس فلا يمتلك أية سلطة وهذا ما يتلاءم مع الطبيعـة التذظيميـة لهذذا الحق(2). فلكي تستطيع الشركة ان تحقق غرضها فانها تسأل عقديا وبما يتفق عليه مسن نشاطاتها بموجب مهام التأسيس وقانونا بما ينص عليه مسن واجبـات كتسيير الاعمـال وطرق الانتخاب ونقل ملكية الاسهم والامور المالية. فلم نجـد فكـرة العقـد هي المنفـردة وانما لاحظنا ان القانون قد وجد كذلك لتذظيم امور الـشركة ممـا حـدا بالفقـه اسـتخدام الفكرة التوفيقية.

\section{ثالثاً: الفكرة التوفيقية}

لقد استمر تكييف نظام الشركة على الاسـاس التقليـدي (الفكـرة العقديـة) لمسدة كانت العلاقات الشخصية قائمة على الاعتبار والمصالح الفردية كسياسة عامة.

(1) رمزي احمد ماضي، المبادئ القانونية الصادرة عن محكمة التميز الاردنية، طا ،صع ا. ( r) Maudce Cozian, Alain Viand ?? -Droit Des Socites Edition 31992 p. 213 


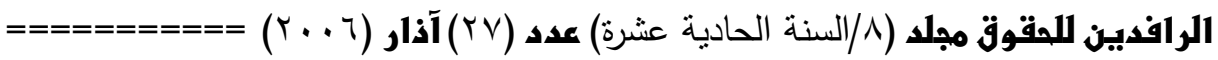

ولما سادت الدعوة الى اعتبار المصالح الوطنية والعامة ممـا دعـا القـانون الى فـتح ابواب تنظيمية لهذا النوع من الشركات. ولما كانت المقارنـة لاتجـاهين لا يتلائمسان مسع الواقع مما دعا الفقه الى ان يوفق بين الفكرتين للالتقاء ولـيس للتفريسق فجـاءت الفكرة التوفيقية لتتوصل الى وصف خاص بها لطبيعة مسؤولية مجلس الادارة خاصسة وبعسد ان ظهر عجز في اعطاء تفسير متكامل لتنظيم هذا النوع من الشركات فظهـر التـداخل بـين الفكرتين واي تفسير لا يخرج عن نطاقهما.

ان تحديد موضوع طبيعة الشركة محل الخلاف المذكور حدا بـالبعض ان يذظر الى الشركة من طبيعة مزدوجة بوصفها عقداً وقانوناً معاً وعلى اسـاس ان مجلس الادارة يعتبر وكيلا عن الشركة ولكنه وكيل من نوع خاص لـ. فهي نظام قانوني وفي الوقت نفسه هي عقـد وان كانـت الـصفة القانونيسة هـي الغالبة(2).ان هذا الرأي قد زاوج بين القـانون والعقـد ورجـح الاول على الثـاني ووضـع بالحسبان ان الوكالة العامة لا يمكـن ان تنطبـق علـيهم فسار مسع بعضض الفقـه لنعـت وكالتهم من نوع خاص ويعلل السبب لطبيعة موكلتهم او مستخدمتهم المعقدة كـشخص معنوي. ان الشركة يحكمها سلطانان، عقد الشركة وقانونها وهذا لا يجوز فـلا بـد مسن عقد الفكرة التوفيقية.

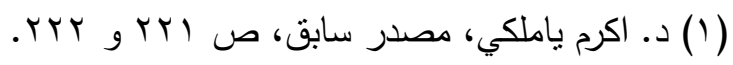

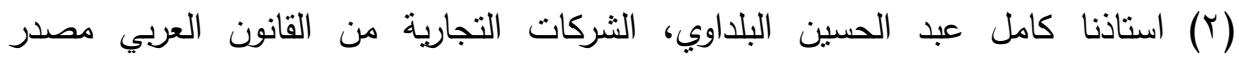

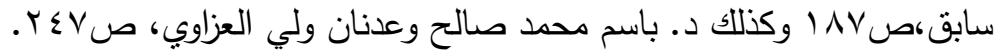


وهناك رأي بموجب هذه الفكرة وهو ان نضع فكرتي العقد والقـانون في الميـزان فيوزن الثقل الاكبر لاعتبار الـشركة قانونيـة والبـاقي لـبعض جوانبهـا العقديـة ويخـص بالذكر التأسيس والانقضاء (1).

ان هذه الفكرة قد جمعت ما شـذعـن الفكرتين العقديسة والقانونيـة لتصوغ منهمـا

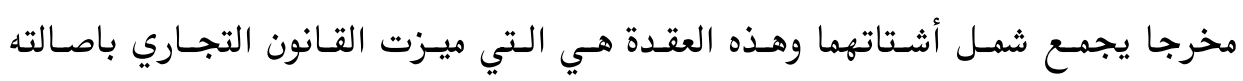
الخاصة فزين هذه الصفة بعض الفقه بان اعتبر العقد ذا طبيعة تجارية(2) لمـبررات دمهج بين العقد والذظام.

ومن الجدير بالذكر ان اعضاء مجلس الادارة لا يعسدون تجــارا على الـرغم مسن احتراف الشركة التجارة واكتسابها حـق التـاجرة لانهـم يعملـون باسـم الـشركة ولسيس

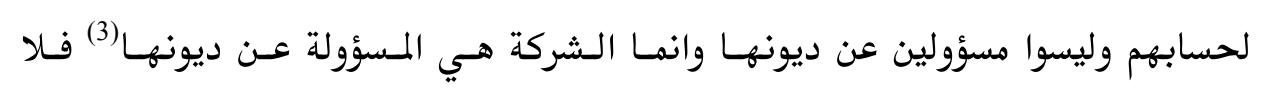
يترتب على افلاس الشركة افلاسهم(4) فعضو مجلس الادارة يكفيه التمتع بالاهلية المدنية لان اعضاء مجلس الادارة ليسو تجاراً وانما يقتصر دورهم على تهيئة النشاط الذي ستقوم به الشركة فالشركة هي التاجرة وقد الغى ريبير وروبلو الصفة التجارية ايضا عن رئسيس مجلس الادارة وان كان تلحقه شخصيا اثار الافلاس والتصفية القضائية (5).

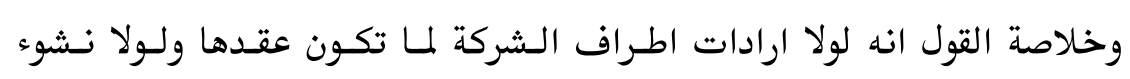
عقدها لما اعترف بها القانون ولولا اعتراف القانون بهذا التشكيل لمـا ولـدت الشخـصية

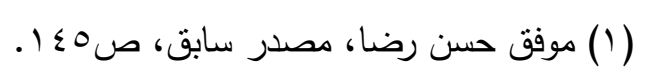

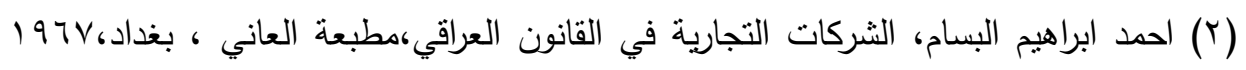

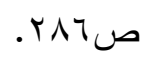

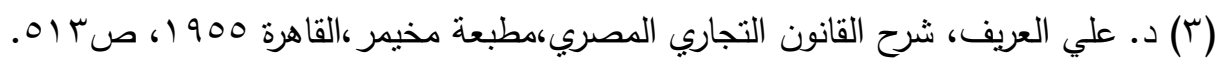

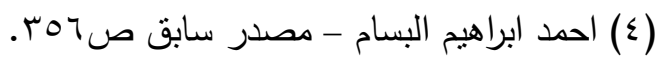

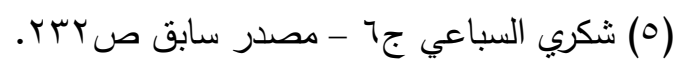




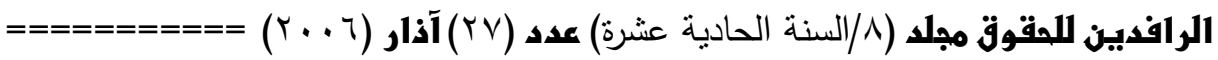

المعنوية (1) ولولا هذه الشخصية لما كانت الحاجـة الى تمثيلها في المجتمع فنظمت بموجب القانون ومن تسميات الشخصية المعنوية اطلقت على الشركات ومنها المساهمة الخاصسة حيث توقفنا امام هذه العقدة الـشائكة لتأويـل وتخـريج هـذه المـشكلة وتـشبثا بالهـدف لتحقيقه فقد تدخل القانون ليحسم الحال فنظمها وجعل صوتها عاليـا لا يقيـده الا هـو وما دام هو كذلك فان ما صح في كل ذلك هو الخضوع لامر القانون فامام الفكرة القانونية فان آلية الشركة تنظم بموجبها وامام الفكرة العقدية فانها تنظيم ما اتفقت عليه اطراف التأسيس وما يحاسب بموجبها كذلك حتى التصفية ونزولا عند هاتين الفكرتين خرجت الفكرة التوفيقية لتوصف العقد الشائكة بموجب هاتين الفكرتين ليس الا لشمولية الالتزام لاعضاء مجلس الادارة بتحقيق الغايةو بذل العناية لكون مهامهما قانونيـة وفنيـة(2) لان مهمتها ليست قانونية . . 1. وليست فنية كذلك ولكن بين بـين(3) فـان الـذي يوظـف الجوانب القانونية هي النسبة الفنية لتفعيل نشاط الشركة. والتذظيم القانوني للشركة وليد لحاجـات المجتمع نظمه القـانون شـأنه في ذلـك شان الخروج من مأزق العقد الكلاسيكي وذلك بان استولد العقد لتنظيم الشخص المعنوي (1) د.حسين يوسف غنايم- قانون الثركات التجارية في دولة الامارات مصدر سابق، سنة .$\Sigma \cdot \Lambda \cdot 19 \wedge \mathrm{V}$

(Y) نقصد بالفن (المهارة) الثخصية والقرة الذاتية في ممارسة عمل معين في اناة وصبر فيرتكز على المواهب والابداع فالفن يرمز الى ما يجب ان يكون وعلم القانون على ما هو به كائن عليه فالادارة ونجاحها تتوقف على امكانيات العنصر البشري والجهود والاخلاص والتفاني وما الادارة الا توجيه للجهد البشري من اجل تحقيق هدف معين ولهذا تكون الحاجة الى مجلس الادارة، د. عبد الغني بسيوني عبد الله - اصول الادارة العامة الدار الجامعية

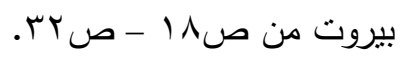

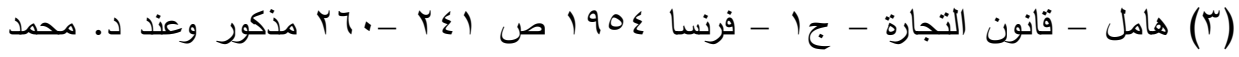
شوقي شاهين - مصدر سابق - هامش(1) ص • ا. 
كاثر له كما هو في العقود الشكلية والاذعان حيث توارت ارادات الاطـراف فـاعتبر عقدـ الشركة من العقود الذظامية وليس مسن العقـود الذاتيـة(1). حيـث ان العقـد التقليـدي في اركانه العامة مشترك مع عقد الشركة اما الاركان الخاصة فهي غير عقد الشركة انما هي وجود كيان قانوني مستقل عن الشركاء فالتطور عن العقد الكلاسيكي هو الادراك المتطور لطبيعة الشركة بوصفها كياناً قانونياً مستقلاً عن العقد(2) ابتغى القانون فيها هدفا لخدمة المجموع استنهض من الواقع وليس خدمة اطراف العقد لعسدم كفايسة التنظيم التعاقدي لحكم نشاط الشركة(3) على علاقاتها الداخلية وانشطتها المختلفة على اساس نظرية العقد فوجد التطور في الفكرة القانونية فالامر يدق في انه لابد مسن النظـرة التوفيقيـة ليتواكـب وجود الشركة مع تطور المجتمع فتغيرت طبيعة الوكالة العامة الاتفاقية الى الوكالـة مسن

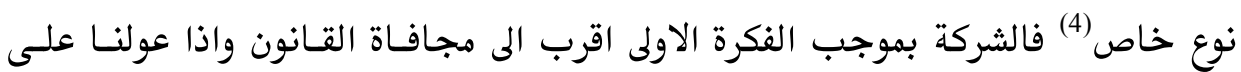
القانون فكاننا اغفلنا العقد وهذا ما لا نرضاه.

فما علينا الا ان نقول كما قال البعض من الفقه (5) لن لكل من الفكرتين مكانتهما الفاعلة في حياة الشركة فكما يستحيل علينا ان نتصور البدء بالاجراءات التأسيسية دون ارادة صحيحة معبر عنها بوضوح يستحيل علينا ايضا تصور استمرار حياة الـشركة دون

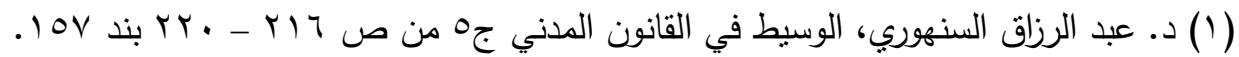

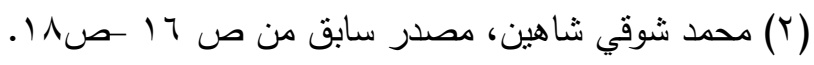

(ع) لقد اخضعت القوانين المشروعات الخاصة للرقابة حماية للصالح العام وفي كل التفاصيل

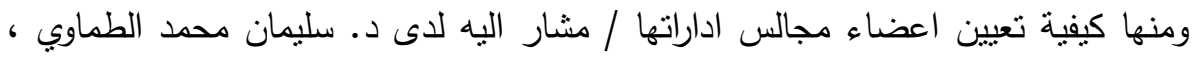

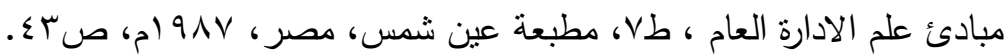

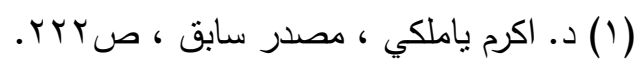

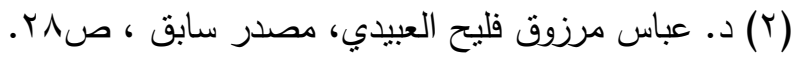




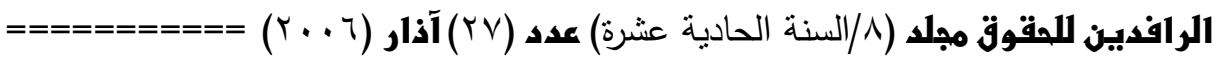

ضوابط تكبح جماح مؤسسيها ومن يتولى ادارتها منعا لمحاولات الاحتيال والغش وحفاظا على الاقتصاد الوطني. ان مسؤولية اعضاء مجلس الادارة تتوزع بين المسؤولية العقدية في حالة الاخلال بالتزام يذظمه عقد الشركة والمسؤولية التقصيرية في حالة الاخلال بـالتزام يذظمسه قـانون الشركات فان دل هذا الارتباط الجدلي على شيء فانما يسدل على ان الـشركة يحكمهـا سلطانان عقد الشركة وقانونها وفق الفكرة التوفيقية لاخضاع احدهما للاخر.

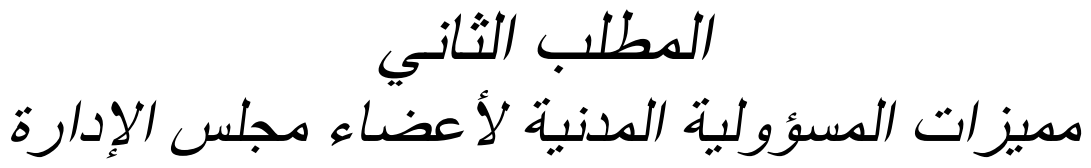
لم تستبين مميزات مسؤولية اعضاء مجلـس الادارة بـشكل واضسح ولكـن يمكن الاستدلال عليهما من خلال نصوص المـواد الـتي نظمتهــا سـواء في القواعـد العامسة او في قانون الشركات.

ان قانون الشركات العراقي نظم هـذه المسؤولية بمـادة واحسدة(1) ولكـن دون ان

يتناول مميزات هذه المسؤولية واسبابها مما استوجب الرجوع الى القواعد العامة لبيان هل ان هذه المسؤولية تضامنية ام فردية وهل ان ابراء الهيئة العامة يعفي من المسؤولية ومـا هي الاسباب التي تؤدي اليها.

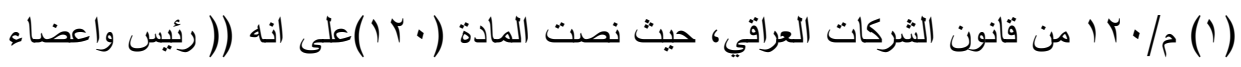

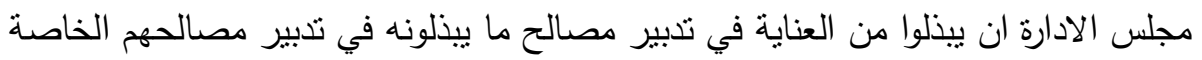

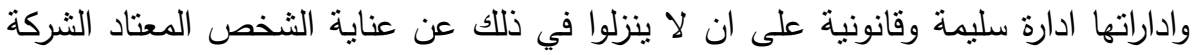

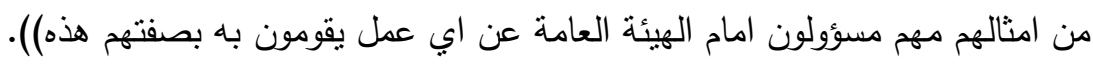


ان مسؤولية اعضاء مجلس الادارة قد تكون مسؤولية عقديسة اذا كـان الاسـاس فيها اخلالاً بالتزام عقدي ومسؤولية تقـصيرية اذا كـان الاسـاس فيهــا اخـلالاً بـالتزام قانوني وتنهض هذه المسؤولية اذا تـوافرت العلاقـة السببية بـين خطـأ اعـضاء مجلس الادارة مجتمعين او منفردين والضرر الذي الحقه ذلك الخطـأ بـالاخرين كمـا ان اعـضاء مجلس الادارة لا تطالهم هذه المسؤولية ما داموا ملتزمين ببذل العنايسة المطلوبـة ، ابتـداء

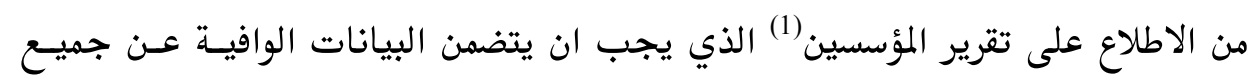
اعمال التأسيس واجراءاته ونفقاته فان هذه المهمة وان كانت من اختصاص الهيئة العامة التأسيسية ولكنها تطال المجلس الذي تعهـد اليـه الهيئسة العامسة بـادارة الـشركة بعسد

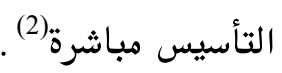
فالاصل ان لا يسأل الشخص الاعن اخطائه الشخصية ولكن قد يسأل مجلس الادارة عن الاخطاء التي ارتكبهـا مجلس ادارة سـابق اذا تسلسسل الخطـأ في عهـد مسن سبقهم ومثاله يأخذ المجلس اللاحق خطأ نتيجة لخطأ المجلس السابق واستمر فيسه(3).

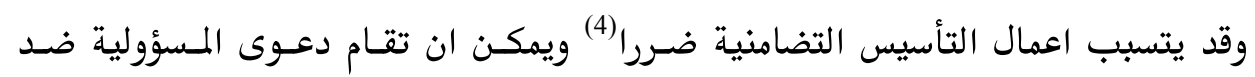
اعضاء مجلس الادارة لان المطلوب من مجلس الادارة ان يتحقق من تأسيس الشركة غـير

(1) ان طبيعة مسؤولية المؤسسين قد تكون شخصية او تضامنية بحسب الاحوال - عمار عامر

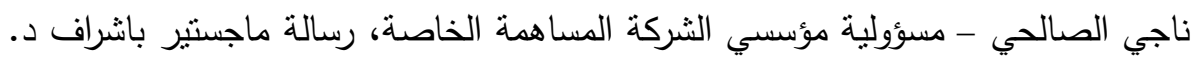

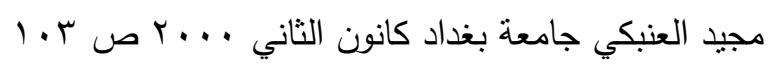

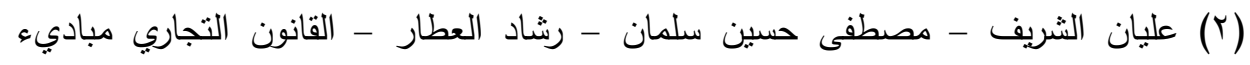

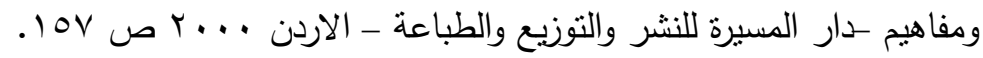

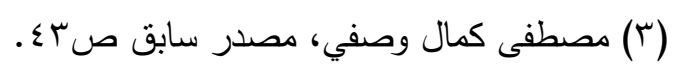

(乏) ولا تتشأ هذه المسؤولية الا اذا قضت المحكمة ببطلان الثركة واكتسب الحكم الدرجة

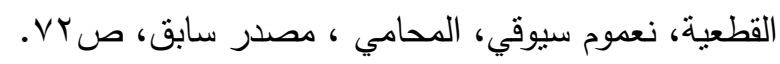




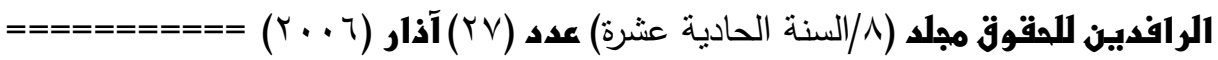

القانوني على الرغم من مسؤولية الهيئة العامة التأسيسية بشرط اخذ الضمانة عـن اقامسة هذه الدعوى ليمنعوا من المبالغة غير المبررة على المؤسسين او استخدامها ورقة ضد اسعار الاسهم من قبل شركة منافسة ويسألون كـذلك اذا كـانوا يعلمسون بالخطسأ وسـاهموا فيسه ومسألة العلم يفصل فيها قاضي الموضوع. وذلك قبل انتخابهم وبعد انتهاء مدة عضويتهم اذا كانوا مشتركين بالمخالفات التي ارتكبها سـلفاؤهم او خلفـاؤهم وفي قرار قضائي ان الدفاع عن العلامة التجارية التي انتقلت ملكيتها عن مدة التأسيس الى الشركة تقع على عاتق مجلس ادارة الشركة المساهمة(1) :

وكذلك يسال اعضاء مجلس الادارة اذا كانت الشركة باطلة وقبل الشخص ادارتها.

ومع كل ذلك فان اعضاء مجلس الادارة لا يلتزمون بـاي التـزام شخـصي فيمـا

يتعلق بتعهدات الشركة وبسبب قيامهم بمهام ووظائف المجلس انما الـشركة باعتبارهـا شخصا معنويا وبوصفها الاصيل الذي بوشرت هذه الاعمال لحسابه فتـؤول الى الـشركة تصرفات مجلس الادارة الصحيحة اذا التزموا باداء واجباتهم المناطة بهم بموجب القانون او عقد الشركة فلا تثقل اشخاصهم ما داموا يعملسون في حسدود صـلاحياتهم (2) فالـشركة تلتزم اذا تمت لحسابها تلك الاعمال فاعمال النيابة عن الشركة لا يسألون عنها شخصيا

(1) احمد سمير ابو شادي - مجموعة القواعد القانونية التي قررتها محكمة النقض - الدائرة

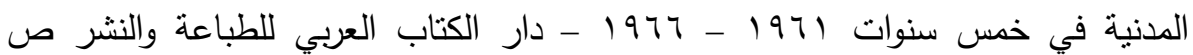

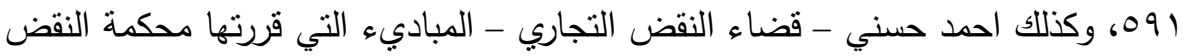

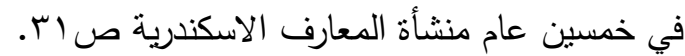
(Y) محمود مختار احمد بربري، قانون المعاملات التجارية - القاهرة- دار الفكر العربي-مصر ص. . 
اذا لم يتجاوزوا(1). واذا بـذل اعـضاء مجلـس الادارة في تنفيـذ واجبـاتهم عنايسة الرجـل المعتاد والتزموا حدود سلطاتهم فلا مسؤولية عليهم سواء حققت الشركة ارباحا ام منيت بخسائر - فالشركة تمارس نشاطاً تجاريـاً والتجــارة تحتمـل الـربح والخسارة (2) وتلتـزم الشركة كذلك بنتائج تصرفات مجلس الادارة، تجــاه الغسير حسسني النيسة اذا تجــاوزوا صلاحياتهم او كان تصرفهم غير قانوني فالشركة ترجع على اعضائها بالتعويض بعد ان تنفذ تصرفاتهم بحق الشركة تجاه الغير حسن النية(3) والقصد من حمايسة الغسير حمايسة للوضع الظاهر ولم يقصد اضفاء الشرعية على تجاوزات المجلس ولم يشر قانون الشركات العراقي الى ذلك ولكن بالرجوع الى القواعد العامة.

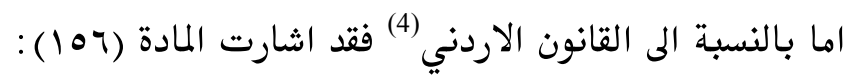
أ - الى ان يكون لمجلس ادارة الشركة المساهمة العامة او مديرها العام الصلاحيات الكاملة في ادارة الشركة في الحدود التي يبينها نظاهها وتعتبر الاعمال والتصرفات التي يقوم بها ويمارسها المجلس ومدير الشركة باسمها ملزمة في مواجهة الغير الـذي يتعامل مع الشركة بحسن نية ولها الرجوع عليه بقيمة التعويض عن الضرر الذي لحق بهـا وكذلك بغض النظر عن أي قيد يرد في نظام الشركة او عقد تأسيسها.

(1) مرتضى ناصر نصر اله ، الشركات التجارية ، مطبعة الارشناد ، بغداد ،1979 ص ro. (Y) د. محسن شفيق - الوجيز في القانون التجاري - دار القصة العربية القاهرة، 194 1، ص .099

(r) د. محمود سمير شرقاوي الثركات التجارية في القانون المصري - دار النهضة العربي -

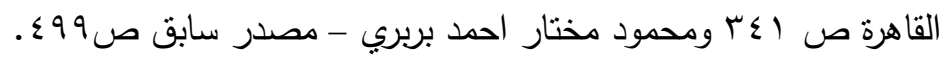

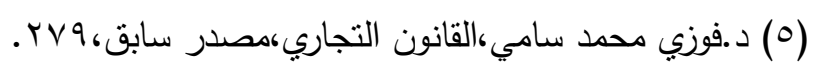




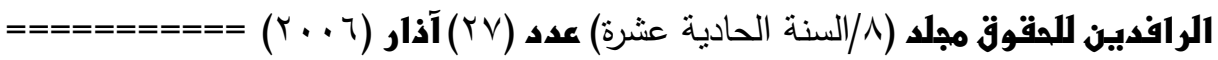

ب - يعتبر الغير الذي يتعامل مع الشركة حسن النية مالم يثبت غير ذلك على الا يلزم ذلك الغير بالتحقق عـن وجـود اي مسند علسى صـلاحية مجلـس الادارة او مسدير

الشركة او على سلطتهم في الزام الشركة بموجب عقدها او نظامها.

ان هذا النص يجعل الشركة تلتزم بالتعويض عن الاضرار التتي يتسببها مسدير

الشركة او أي عضو مسن مجلس الادارة عسن الاعمـال الـتي يمارسهـا باسـم الـشركة والتعويض للمتضرر تجاه الغير حسن النية اما القانون الاردنسي (1) فقـد اثـار الى هـذه ئه الحماية واعمالها ملزمة في مواجهة الغير حسن النية(2) ولكن قانون الشركات العراقي الاسبق اشار الى حالة التعامل مع الغير حسن النية(3) اما اذا كان الحال بعكس ذلك بان مجلس الادارة قام باعماله بحسن نية فقد اشار الفقه الى اعفاء اعـضاء المجـالس الادارية من كل مسؤولية فيما اذا ثبت لها حسن نيتهم في اثناء نظر اية دعـوى امـام المحاكم ضد عضو مجلس الادارة انه قام باعماله بحسن نية وترو فيجب اعفاؤه بدلا من تهمته بالاهمال وخيانة الامانة فيسوغ للمحكمة ان تعفيه مسن المسؤولية كلهها او بعضها بناء على الشروط التي تستصوبها (4). فعلى مجلس الادارة السهر والاخلاص والصدق باعمـال الـشركة كافـة لتحقيـق غرضها اما اخطاء مجلس الادارة ومخالفاتهم لواجباتهم وغشهم واساءة استعمال السلطة وعدم بذل العناية المطلوبة فيلاحق عمـل مجلـس الادارة القـضاء ولايوكـل الـيهم تقريسره

$$
\text { (1) (1) م/ (107 من قانون الثركات الاردني. }
$$

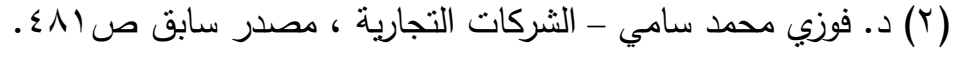

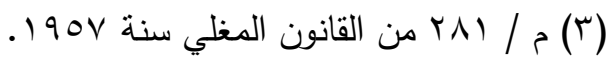

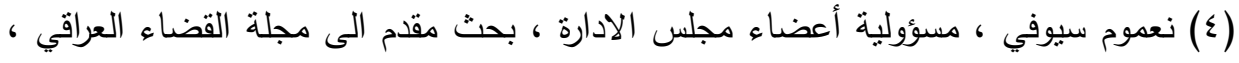

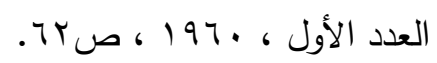


حتى لو اجازتهم الهيئة العامة لكي لا يكون المجلس خصما وحكما في ذات الوقـت (1) فهم مسؤولون حتى عن الخطأ البسيط(2) وسنوضح ابراء الهيئة العامسة لاحقـا في معسرض لهرض الحديث عنها في حالات المسؤولية ولكن هل ان المسألة سـتلحق اعسضاء مجلس الادارة بصيغة التكامل والتضامن ام بشكل اخر. ان من الفقه من قصر قيام التضامن عند القيام بعمل غير مشروع حصرا(3)واخـر يشير الى انه لا يقع التضامن الا استنادا الى اتفاقهما والقانون وواقع الحـال لا يـشير الى ذلك(4) ، كما ان بعض الفقه(5) اسند اعمال التضامن ايـضاً الى ان اعمـال مجلس الادارة اساسها الوكالة التي تربطهم بالشركة وانها تعتبر عقـدا مسن طبيعـة تجاريسة فالتـضامن مفروض في المعاملات التجارية فيسأل الاعضاء المتعددون عن تعويض الـضرر الـذي حـل بالشركة بالتضامن.

ويرى البعض انه يوجد استثناءان يردان على القاعـدة الـتي توجـب الـنص او

الاتفاق على التضامن وذلك في مسألتين اولهما التجارية وثانيهما في المسائل التقصيرية(6) ونطاقها تعدد المسؤولين عن عمل غير مسروع كـانوا متـضامنين عـن التـزامهم بتعـويض الضرر دون تمييز بين الفاعل الاصلي والشريك المتسبب(7).

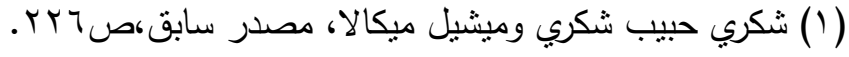

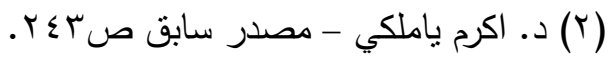

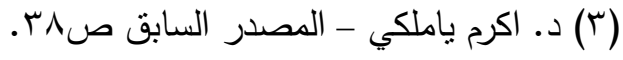

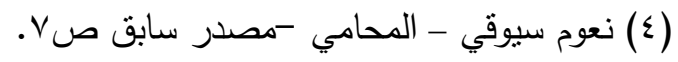

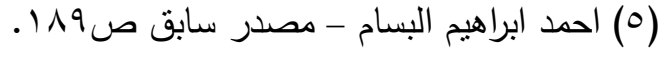

(7) نواف حازم خالد - الالتزام التضامني - رسالة دكتوراه مقدمة الى كلية القانون جامعة صلئ

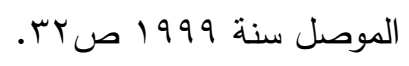

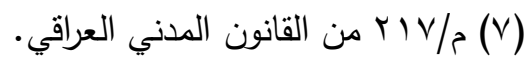




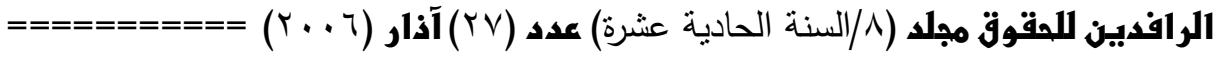

اما القانون الاردني (1) فقد اشار بشكل واضح الى ان رئيس واعضاء مجلس الادارة مسؤولون تجــاه الـشركة والمسساهمين والغسير عـن كـل مخالفـة ارتكبهــا أي مسنهم او جميعهم للقوانين والانظمة المعمول بها وعسن أي خطـأ في ادارة الـشركة ولا تحسول موافـق الهيئة العامة على ابراء ذمة مجلس الادارة دون الملاحقة القانونية لرئيس واعضاء مجلس الادارة واوضح كذلك(2) ان المسؤولية التي اشار اليها انفا تكون اما شخـصية تترتـب على الـى عضو او اكثر من اعضاء مجلس ادارة الـشركة او مسشتركة بسين رئسيس واعـضاء المجلس ويكونون جميعهم بهذه الحالة الاخيرة مسؤولين بالتـضامن والتكافـل عـن التعـويض عـن الضرر الذي نتج عن المخالفة او الخطأ على ان لا تشتمل هـذه المسؤولية أي عـضو اثبـت اعتراضه خطيا في محضر الاجتماع على القرار الذي تضمن المخالفة او الخطأ . ويشير الفقه (3) الى ارتباط المسؤولية بالتضامن والتكافل تجاه من يتـضرر نتيجـة التهـ تقصيرهم او اهمالهم في ادارة الشركة في معرض اتخاذ قـرارات مجلـس الادارة بالاكثريسة عدا من يعترض ويثبت اعتراضه خطيا في محضر الاجتماع. اما القانون الفرنسي فلا يوجد نص يقـرر التـضامن بـين المسؤولين تقـصيريا ولكـن القواعد العامة(4) نصت على ان "كل شريك في الخطأ مسؤول عـن الـضرر كله وان قـانون الشركات الفرنسي(5) يجعل قرارات الجمعية العمومية لا تحول دون مسؤولية اعضاء مجلس الادارة عن الاخطاء الادارية التي يرتكبونها ويسأل اعضاء مجلس الادارة شخـيا او على

$$
\begin{aligned}
& \text { (1) (1) م/ مقرة أ من قانون الثركات الاردني }
\end{aligned}
$$

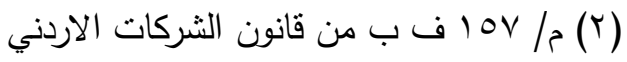

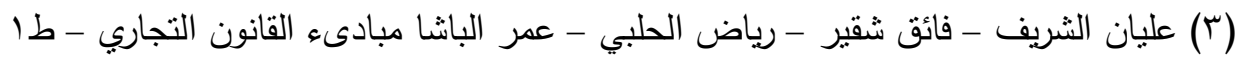

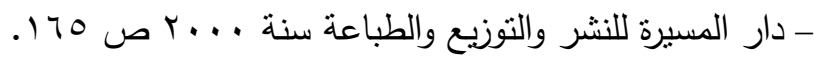

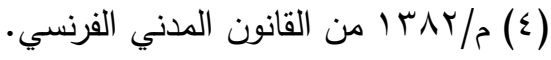

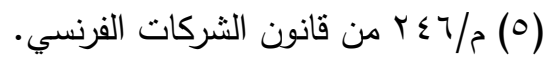


وجه التضامن من حيث الحالات تجاه الشركة او تجاه الغير عما يرتكبونسه مسن مخالفـات

استجابة للقوانين المطبقة على الشركات وخرق النظام الاساسي او خطأ الادارة(1).

اما الفقه والقضاء الفرنسيان فيميزان بين التضامن الكامل والتضامن غير الكامل (2)

ولكن قد ترك هذا التمييز فلا يوجد الا نوع واحد من التضامن هو التضامن الكامل.

والقانون المدني الفرنسي ينص صراحة على ان مصدر التضامن هو الاتفـاق(3) او

نص القانون شانه في ذلك شأن القانون العراقي (4). فالاصل في مسؤولية اعضاء مجلس الادارة هـو التـضامن مادامست ادارة الـشركة ناجمة عن الادارة الجماعية الا ان هذه المسؤولية تخرج عن الاصل الى الفرديسة في حالـة الخطأ غير المسشترك وفي حالـة الاثبـات في الاعستراض على القـرارات والغيـاب بالعـذر المشروع في جلسة صحيحة لمجلس الادارة. وقد تتأتى اسباب مسؤولية اعضاء مجلس الادارة اما بمخالفة القانون او مخالفـة النظام الاساسي او خطأ الادارة. ولما كان وصف المسؤولية نابعا من اساسها(1) القانوني او

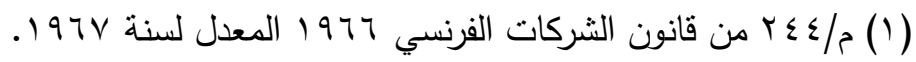

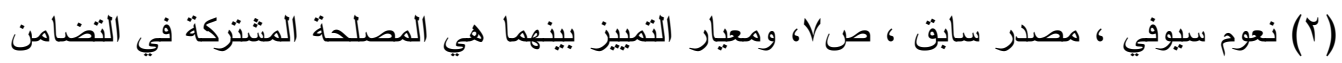

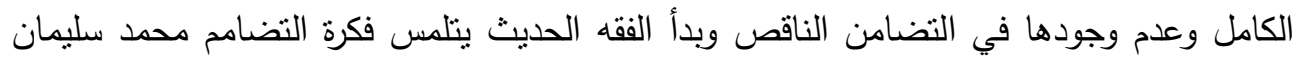

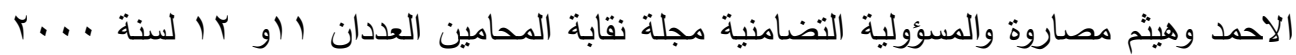

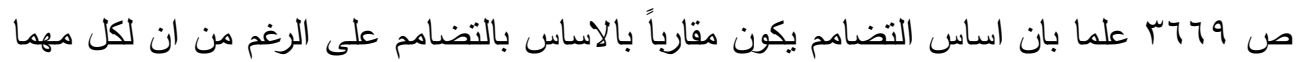

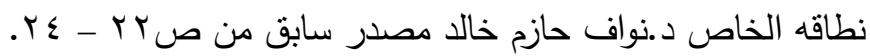

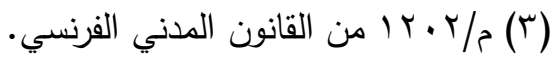

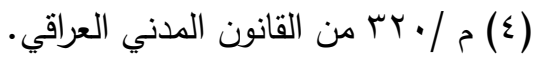




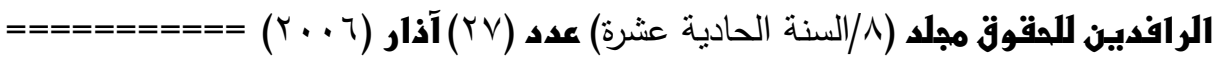

العقدي فقد توصف هذه الاسباب كذلك باسباب المسؤولية التقصيرية باعتبار انها ناشئة عن مخالفة قاعدة في القانون ومسؤولية عقدية نابعة عن مخالفة العقد. لقد نظم القـانون العراقي (2) شـأنه في ذلـك شــأن القـوانين المقارنسة جملـة مسن الوظائف التي يجب ان تنهض بها ادارة الشركة بواسطة مجلس ادارتها وعليه فان عدم تنفيذ المجلس لهذه الوظائف او التعسف في استعمالها يرتـب عليسه المسؤولية والامثلـة على ذلك كثيرة منها عدم دعوة الهيئة العامسة بالـشكل المقرر او الاشـتراك في شـركات منافسة او مماثلة او عدم اعسداد التقـارير والحـسابات في المـدة المحسددة او عسدم تقـديم البيانات التي يطلبها المفتش (3) او عدم الالتزام بتنظيم الامور المالية والمحاسبية والادارية للشركة المساهمة بموجب انظمة داخلية خاصة يعدها مجلس ادارة الشركة كما هو الحال في القانون الاردني الذي يستوجب تنظيم داخلي للشركات ويحدد فيهـا بـصورة مفـصلة واجب المجلس وصلاحياته.

ومن اسباب المسؤولية كذلك مخالفة قرارات الهيئة العامـة كونهـا اعلى هيئسة فهي تنتخب لعضوية مجلس الادارة ممثلي المساهمين(4) وتقيلهم وتناقش تقـارير مجلس الادارة وحساباته الختامية واقرار الخطة السنوية المقترحسة والموازنـة التخطيطيـة واقـرار

(1) (1) تقصد بالقانون هو الثركات والقانون المدني.

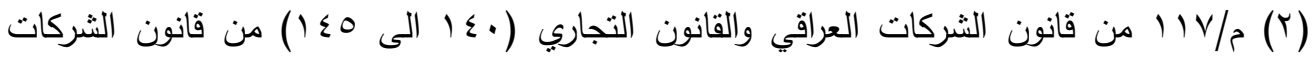
الاردني.

$$
\begin{aligned}
& \text { (ז) م/؟ ؛ ا من قانون الشركات العراقي. } \\
& \text { (ع) م / ـ • ا / / من قانون الثركات العراقي }
\end{aligned}
$$


نسبة الارباح الواجب توزيعها وتحديد نسبة الاحتياطي ويكـون مجلس الادارة مسؤولا قبلها تبعا لذلك (1).

وكذلك من اسباب المسؤولية الخطأ في الادارة ولم يفرق بعض الفقه بسين الخطـأ

في الادارة ومخالفة القانون فالخطأ في الادارة يتضمن جميع اسباب المسؤولية فهو الشرط العام الذي يغني عن تقسيم اسباب المسؤولية ويوعزها الى النظرية العضوية والـتي تكـون دائما مسؤولية تقصيرية وهي المواقف التي تشكل اخلالا بواجب العناية المعتادة في ادارة الشركة التي اوجبها القانون. ولكن بعض الفقه فرق بين الخطأ في الادارة وبسين مخالفـة القانون. فالخطأ في الادارة هو السبب التعاقدي للمسؤولية في مواجهة الـشركة ومخالفـة القانون هي سبب المسؤولية التقصيرية في مواجهة الغير(2). اما الغش فانه يفسد كل شيء فله مفهوم واسع ومسؤولية اعضاء مجلس الادارة عن جميع حالات الغش اتجاه الشركة والمساهمين والغير(3) وعموما فان اسباب المسؤولية لا يمكن حسصرها بمسسميات معينـة فقـد تكسون الى جانـب المسؤولية المدنيـة المسؤولية

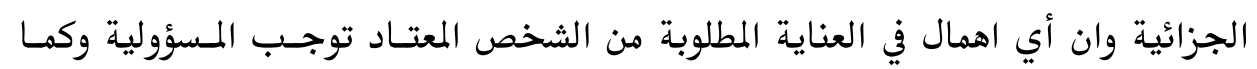
يشير اليه بعض الفقه كما اشرنا حتى عن الخطأ البسيط(4).

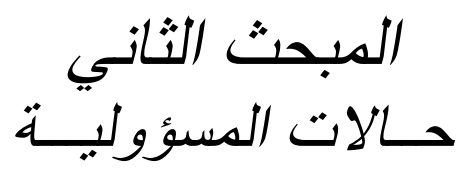

$$
\text { (Y) }
$$

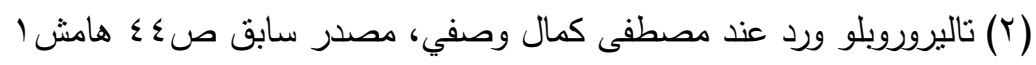

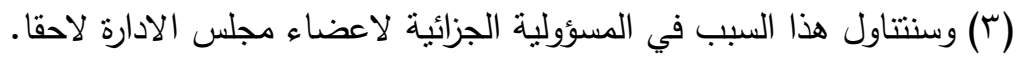

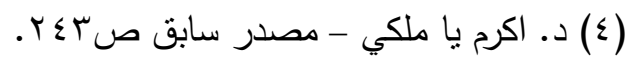




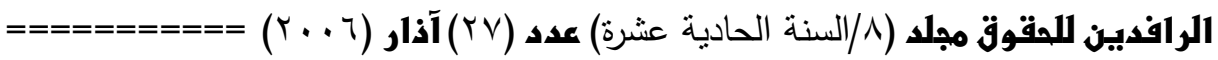

يلزم القانون رئيس واعضاء مجلس الادارة ان يبذلوا من العناية في تدبير مصالح

الشركة ما يبذلونه في تدبير مصالحهم الخاصة على ان لا تقل هـذه العنايسة عـن عنايسة

الشخص المعتاد من امثالهم فيكونون مسؤولين عن أي عمل يقومون بـه بصفتهم هذه قبل الشركة (الهيئة العامة) وقبل المساهمين وقبل الغير أي كل مسن لـه تعامسل مـع الـشركة وتتحقق مسؤوليتهم عند مخالفتهم لاحكام القانون او قرارات الهيئة العامة او الخطـأ في الادارة او عن جميع اعمال الغش. ولاجل بيان حالات هذه المسؤولية سنقسم هذا المبحث الى ثلاثة مطالب وكما يأتي : المطلب الاول: مسؤولية اعضاء مجلس الادارة قبل الشركة المطلب الثاني : مسؤوليـة اعضاء مجلس الادارة قبل المساهمين. المطلب الثالث: مسؤوليـة اعضاء مجلس الادارة قبل الغير.

\section{المطلب الأول}

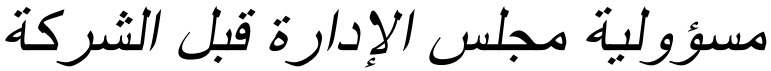

تنشأ المسؤولية اما لعدم بذل العناية المطلوبة من الشخص المعتاد وعـدم تحقيـق

الغاية الـتي اسـتوجب علـى مجلس الادارة اداؤهـا فيسـأل اعـضاء مجلس الادارة عـن اخطائهم (1) فتقع المساءلة على جميع الاعضاء بوصفهم شخصا واحسدا حتـى لـو فوضست السلطة لواحد او اكثر من الاعضاء كما ان المسؤولية في الوقـت ذاتـه تنطبـق على حالـة

(1) د. اكرم يا ملكي - و د. باسم محمد صالح،مصدر سابق ص r r . 
الشخص الذي ارتكب امرا يستوجب المؤاخذة طبقا للقواعد العامة وما نص عليه القانون كذلك باعتبار خطائه الشخصي فاذا وقع الخطأ من مجلس الادارة بأجمعه وكـان قـراره بالاجماع فان جميع اعضاء المجلس يسألون فللشركة رفع دعوى المسؤولية على الاعضاء مجتمعين وعلى العضو الذي يتسبب في الحاق الضرر بالشركة(1). لقد عالج المشرع العراقي مسؤولية مجلس الادارة قبل الـشركة مسن خـلال مـادة واحدة فقط اذ الزم رئيس واعضاء مجلس الادارة ان يبذلوا من العنايسة في تـدبير مسصالح الشركة ما يبذلونه من تدبير مصالحهم الخاصة وادارتها ادارة سليمة وقانونية على ان لا ينزلوا في ذلك عن عناية الشخص المعتاد من امثالهم(2) وان يقومسوا بـادارة الـشركة على

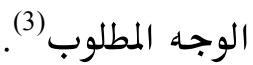

فالقانون قد اخذ في موضوع العناية بالمعيار الموضوعي بحـده الادنسى(4). ويكـون

المعيار شخصياً اذا تجاوزه المعيار الموضوعي (5). ولو سلمنا جدلا ان مسؤولية اعضاء مجلس الادارة تجاه الشركة مسؤولية عقدية مبناها عقد الوكالة الذي يربطهم بالشركة(6) ولكن نجد ان القانون قد فرض على مجلس (1) عز الدين الديناصوري والدكتور عبد الحميد الثواربي المسؤولوية المدنية في ضوء الفقه

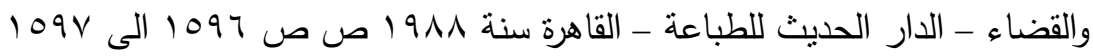

$$
\text { (Y) المادة (Y) (Y) من قانون الثركات العراقي. }
$$

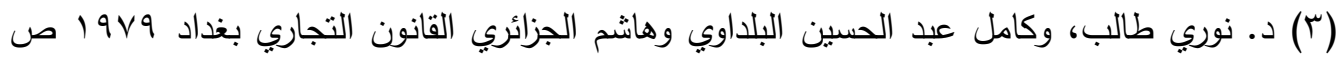

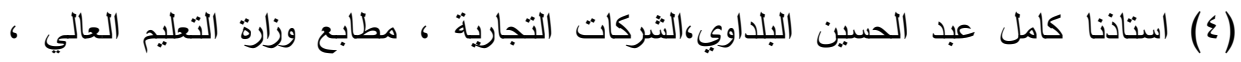

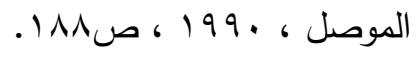

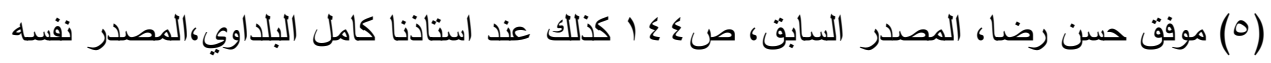

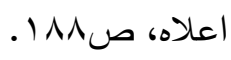

(7) د. اكرم باملكي ود. فائق الثماع، مصدر سابق، ص170 1. . 


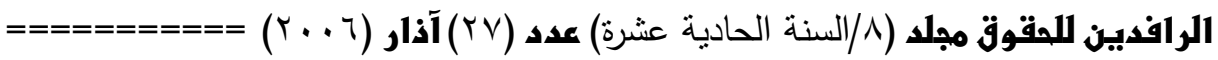

الادارة مجموعة من الوظائف والزمه بادائها بحيـث لا ينـزل عـن العنايـة المطلوبـة لان النزول عن هذه العناية يعـرض مجلـس الادارة الى المسؤولية التقـصيرية والـتي اساسـها القانون. عليه يمكن القول ان المسؤوليتين العقدية والتقصيرية تنـال مـن اعـضاء مجلـس

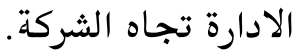

ومن امثلة الاخطاء التي يرتكبها مجلس الادارة ويتسبب مسؤوليته قبل الشركة. اندفاع المجلس في مضاربات خطيرة تفـوق امكانيـات الـشركة وتتنـافى وقواعـد حسن الادارة مما يؤدي الى الحاق الخسائر بالـشركة وتهديـد مركزهـا المـالي. غـير ان اعـضاء مجلس الادارة لا يسألون عن الخسائر التي لم تكن ناتجة عن خطأ يعود اليهم او انهـم لم يتمكنوا من منعه مهما بذلوا من عناية وحرص في ادارة الشركة(1). ويشترط في الضرر الذي نجم عن اخطاء مجلس الادارة ان يكـون ضـررا محققـا

\section{وليس احتماليا وان يكون مباشرام).}

ويجب ان تتوافر العلاقة بين الخطأ والضرر فان انتفت العلاقة السببية بينهمـا فلا تنهض المسؤولية كما لو تحقق سبب اجنبي قطع العلاقة بين الخطأ والـضرر كـالقوة القاهرة والحادث المفاجيء او فعل الغير(3) عندها تذصرف اثار تسصرفات مجلس الادارة الى الشركة وليس الى اعضاء مجلس الادارة استنادا الى فكرة النيابة التي تحل فيها ارادة النائب الذي هو مجلس الادارة محل ارادة الاصيل المتمثل بالشركة.

ولكن لو قام المجلس بتصرفات خارج اختصاصاته متجاوزا فيها حسدود نيابتهـ

فهل تلتزم الشركة بهذه التصرفات ام لا. الجواب يعتمد على اقرار هذه التصرفات مسن

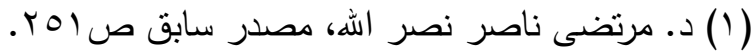
(Y) ( 
عدمه والاجدر هو الاعتمـاد على الظـاهر وحمايسة الـشركة مسن تجـاوز الاعـضاء حسدود سلطاتهم (1) التي تضر الشركة.

اما القانون الاردني (2) فيشير الى انه يسال اعضاء مجلـس الادارة عـن اخطـائهم في الادارة وعن جميع اعمال الغش واساءة استعمال السـلطة وعسن كـل مخالفـة للقـانون

ونظام الشركة فالاخطاء التي يترتب عليها الحاق الضرر بالشركة تستوجب التعويض(3). وترفع دعوى الشركة على مجلس الادارة باعتبار الشركة شخصية معنوية فيحق لها اقامتها عن تصرفات مجلس الادارة الـتي تسببب ضسرا للـشركة لغسرض التعـويض استنادا الى ان الضرر الذي اصاب الشركة أي مجموع المساهمين اما من قبـل الشركة او من قبل المساهم. فالدعوى المقامة على مجلس الادارة من قبل الشركة التي ترفعهـا الـشركة عـن طريق ممثليهـا القـانونيين ويمكـن ان يرفعهـا مجلس الادارة الجديسـ (4) او عسن طريسق المصفي (5) كما يحق لمراقب الشركات اقامة هذه الدعوى وفقاً للقانون الاردني (6).

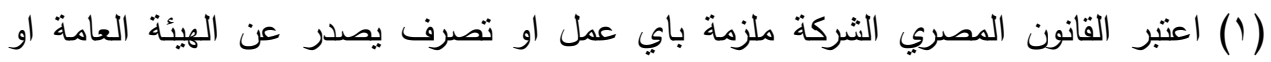

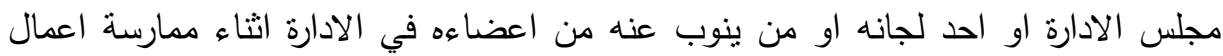
الادارة على الوجه المعتاد.

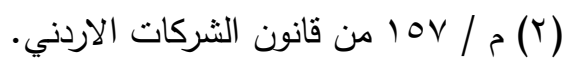

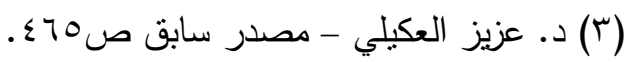

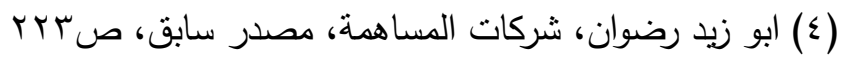

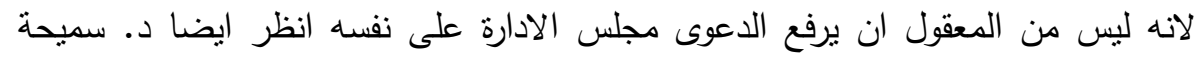

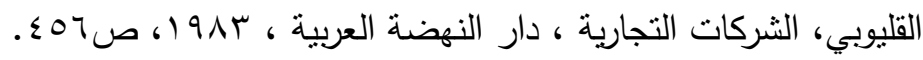

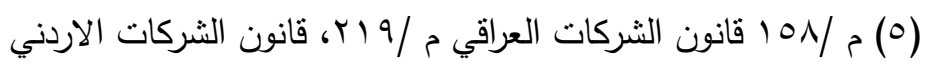

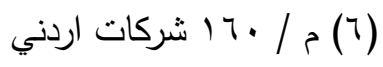




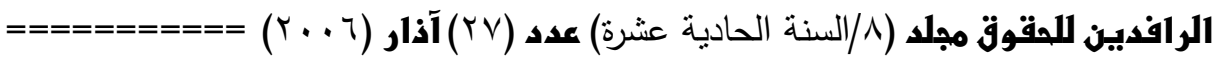

وقد تسمى هذه الدعوى دعوى الشركة التي ترفعهـا الهيئـة العامسة لمـا للهيئسة

العامة من سلطة عليا فانهـا اعلى هيئسة في الـشركة(1) وتتـولى تقريسر كـل مـا يعسود الى لى مصلحتها وتمثل جميع المساهمين وترعى مصالحهم كصلاحية المحافظة على حقوقهم اذا تبين ان مجلس الادارة قد تجاوز صلاحياته وخالف القوانين او عقد الشركة ونظاهها

والحق خسارة فيها.

وقد ضمن قانون الشركات الاردني التوسع في مسؤولية رئيس (2) واعضاء مجلـس

الادارة وذلك عن جميع اعمال الغش واساءة استعمال السلطة وعن كـل مخالفـة للقـانون

وعن الخطأ في الادارة.

وتتسم دعوى الشركة ان المدعي هو المتضرر (الشركة) وعليه يقع اثبـات الخطـأ

بطرق الاثبات كافة والمدعى عليهم هم اعضاء مجلـس الادارة والمسؤولون عـن اخطـائهم الادارية طوال مدة وظيفتهم والفصل في تقدير الخطأ والعلاقة بين الخطأ والـضرر تفـصله

المحاكم بمراقبة محكمة التمييز(3).

والسؤال الذي يمكن اثارته انه هل يمكن اجراء المسصالحة او التنـازل عـن هـذه

الدعوى؟ ان القانون العراقي لم يذص على ذلك وبالرجوع الى القواعـد العامـة فانسه يقـع

باطلا كل شرط يقضي بالاعفاء من المسؤولية المترتبة على العمل غير المشروع وهذا يجنب

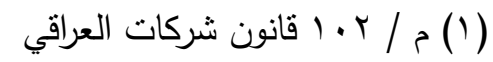

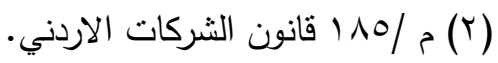

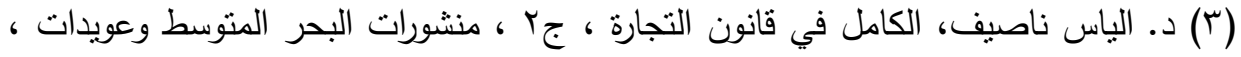

باريس،r|919 ،صع آس. 
الشركة من تأثير مجلس الادارة في الهيئة العامة او ان توقع الهيئة العامة على المصادقة

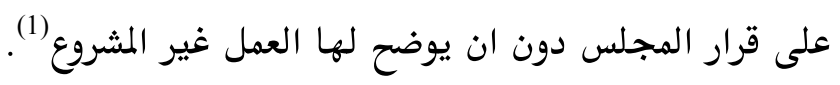

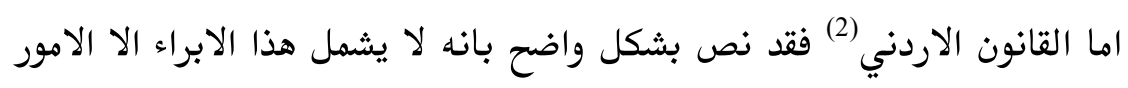
التي تمكنت الهيئة العامة في معرفتها(3) ولكـن اعطى الاسـتثناء على نـص الاحتجــاج بالابراء الصادر عن الهيئة العامة(4) الا اذا سبقه بيان حسابات الشركة السنوية واعـلان تقرير مدقني الحسابات واجد ان النص الاردني اجدر بالتأييد وادعو المشرع العراقي الى الاخذ به استقراراً لسير وديمومة الشركة.

اما القانون الفرنسي فقد نفى سقوط دعوى المسؤولية ضد اعـضاء مجلس الادارة

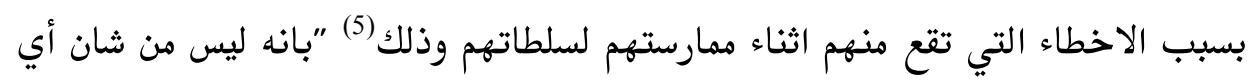
قرار يصدر عن الجمعية العامسة ان يسسقط دعـوى المسؤولية ضـد اعـضاء مجلس الادارة بسبب خطأ ارتكبوه في تنفيذ مهامهم " وان الابراء من الهيئة العامة لا يعطل او يعفي من دعوى المسؤولية عن الاخطاء المرتكبة عن مباشرة اعمال الادارة.

(1) في قرار قضائي عن محكمة القاهرة الابتدائية سنة . ب9 1، ان اعضاء مجلس الادارة تتنهي

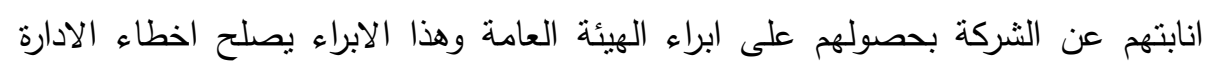

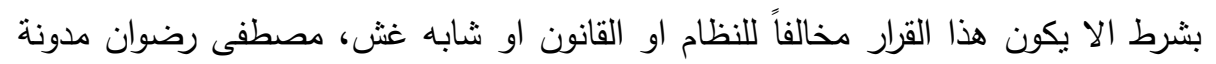

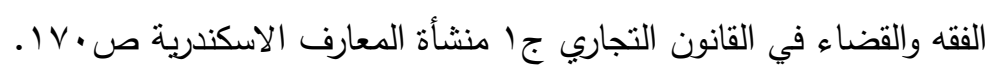

$$
\text { (r) }
$$

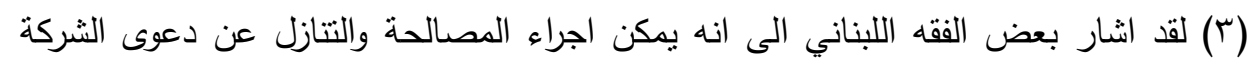

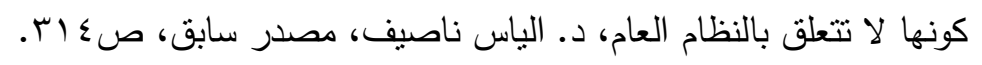

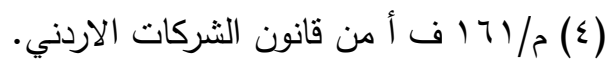

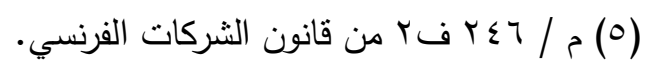




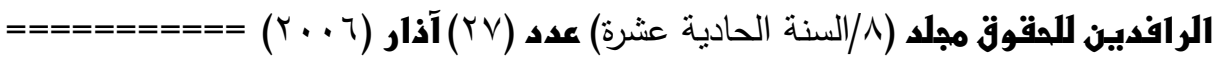

وقد يبرأ القضاء اعضاء مجلس الادارة عن اخطاء الادارة من قبل الهيئة العامسة

ويطهر ذمة الاعضاء التي تمس التقارير والميزانية المقدمة لها ويعتبر ابراء لذمسة المجلس عن كل التزام خاص بادارة السنة المالية المنصرمة(1) ويعفى من المسؤولية مسن لم يـشترك في العمل موضوع المسؤولية بشرط ان لا يكون عـدم اشـتراك العـضو في الفعـل الـضار قـد رهـ اقترن لاهماله في الاشراف على شؤون الشركة ورقابة امورها بحيث لو قام بـاداء واجبـه بهذا الشأن ما كان هناك مجال لوقوع الخطأ() اما عن اصول رفـع الـدعوى فـان قـانون المرافعات المدنية(3) تولى تنظيمها وفي قرار قضائي اوضح للمحكمة الـتي يقـع في دائرتهـا اختصاصها مركزي الشركة ليست هي المرجع الوحيد المخـتص بذظـر الـدعاوى المتعلقـة بالشركات وانما يقبل الادعاء على الشركة ايضا في المكان الذي تم فيه التعهـد او الـذي يعين لتنفيذ التعهد او جرى فيه تسليم المـال او وقـع فيسه الفعـل المسبب للدعوى واذا تجمعت حالتان او اكثر من حالات الاختصاص فيكـون للمسدعي الخيسار بـين أي منهـا حتى لو كانت الدعوى مقامة على الشركة(4).

(1) استنئاف الاسكندرية 190r - مصطفى رضوان - التشريع والقضاء، مصدر سابق، بدون

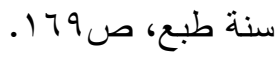

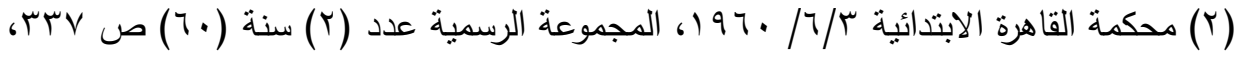
مصطفى رضوان، مدونة في الفقه والقضاء في القانون التجاري، جا منشأة المعارف التهده

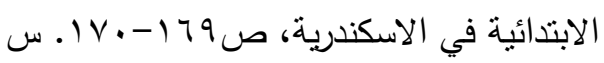
(r) قانون المرافعات المدنية العراقي رقم به لستنة 1979 المعدل وقانون المرافعات الاردني رقم ع السنة 1911.

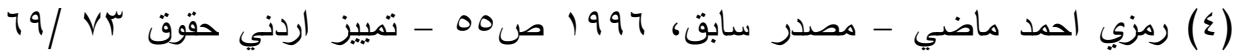
صفحة برى سنة 1979. 
واما الدعوى المقامة على مجلس الادارة من قبل المساهم تسمىى دعـوى الـشركة

الفردية او الدعوى الشخصية ففضلاً عن اقامة دعوى الشركة على مجلس الادارة من قبل الهيئة العامة هي الاصل كونها صاحبة الاختصاص واعلى سلطة في الشركة ولكن اذا ما تضرر احد المساهمين او بعضهم نتيجة خطأ ارتكبه مجلس الادارة او احد اعـضائه عنـد قيامهم باعمال باسم الشركة ولحسابها نشأ عن ذلك حق للمساهم او مجموعة المساهمين في رفع الدعوى امام المحاكم المختصة للتعويض عن الضرر (دعوى حق خاص) (1) او لكل مساهم لحقه ضرر من مخالفة النصوص القانونية او التعاقدية للشركة ان يرفع السدعوى للحصول على التعويض المناسب للضرر(2). فالمساهم الذي يختصم مجلس الادارة مطالبا اياه بالتعويض عـن الاضـرار الـتي لحقت بالشركة له سند في ذلك ان الضرر لا يقتصر على الـشركة فقـط وانمـا يتـأثر بـــ المساهمون كذلك خاصة اذا تقاعست الهيئة العامسة عـن اقامسة دعـوى الـشركة ويقيمهـا عندئذ المساهم او عدة مساهمين(3) دفاعا عن مصالح الشركة عندما تتعرض للـضرر جـراء تصرفات اعضاء مجلس الادارة ولكن ما هو الاساس القانوني الذي يستند اليه المساهم في اقامة هذه الدعوى خاصة وانه لا يحق مقاضاة مجلس الادارة الا عن طريق الهيئة العامة لانه لا علاقة عقدية او قانونية مع المساهم مباشرة حيث يشير بعض الفقه (4) الى انه مـا

(1) زياد رمضان - اساسيات في الادارة المالية - دار الصفاء للنشر والتوزيع - عمان الاردن

$$
\text { . 1999 } 199
$$

(r) د. محمد خليل الحموري، حماية ملكية المساهمين او الشركاء في الثركة المساهمة الخصوصية والثركة ذات المسؤولية المحدودة - دراسة مقارنة - مطبعة التوفيق طايه ماهيه - عمان

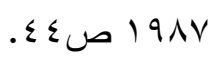

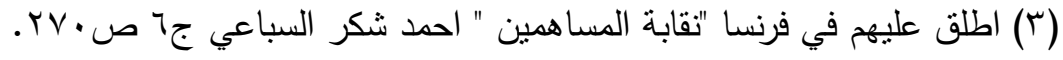

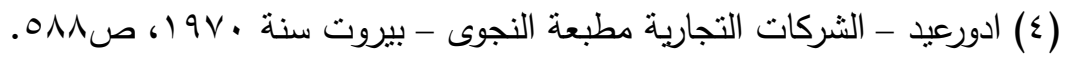




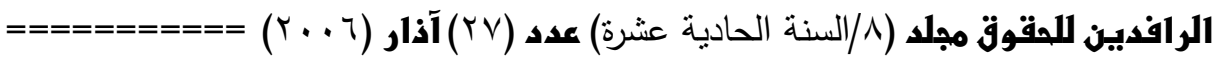

دامت مسؤولية مجلس الادارة عن حسن ادارة الشركة هي مسؤولية مصدرها القـانون ولا يجوز الاعفاء منها او التخفيف فيها فانسه يكـون مسن حسق كـل مسساهم مباشـرة دعـوى ري الشركة ان لحق بالشركة اضرار من تصرفات مجلس الادارة. اثرت في مركزها ككل وانعكست من ثم على المساهمين كافراد فيكون مسن حسق

المساهم ان يباشر دعوى المسؤولية المدنية في مواجهـة رئسيس واعـضاء مجلس الادارة اذا اثبت ان ضررا لحقه منهم لـذلك يـتعين علسى المساهم المـضرور اثبـات الخطسأ والـضرر والعلاقة السببية لكي ينجح في دعواه('). ولاجل اقامة الدعوى فان قانون المرافعـات يفـرض ان يكـون رافـع الـدعوى ذا صفة فيجب ان يكون مساهما وهذا ما ذهب اليه قضاء محكمة التمييز العراقيـة ان بيـع الاسهم يفقد صفة العضوية من الشركة فلا يحق له السير في الدعوى وتكون الدعوى قـد فقدت المصلحة والصفة فتكون الخصومة غير موجهة (2) كمـا انهـا لا تقـام مسن المساهم القديم لان هذه الدعوى تنتقل مع السهم(3). وتقام الدعوى في حالة تقاعس الهيئة العامة عن اقامتها ام امتناع الـشركة عـن اقامتها من قبل ممثليها بسبب الاهمال او التواطؤ مع الهيئة العامة(4).

(1) د. حسني المصري، القانون التجاري وشركات القطاع الخاص، الكتاب الثاني، طا، . TVV ص (1917

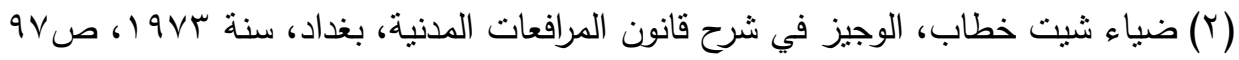
ص19.

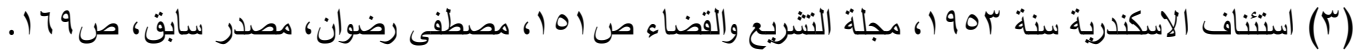

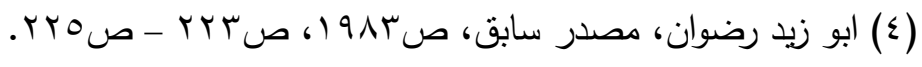


واذا اقيمت الدعويان فيمكن اما توحيدهما او سقوط الدعوى التي يقيمها المساهم

او عدم اجازة الدعوى الثانية(1).

ان القانون الاردني قد نص على حق المساهم في اقامة دعوى الشركة فاجاز لاي

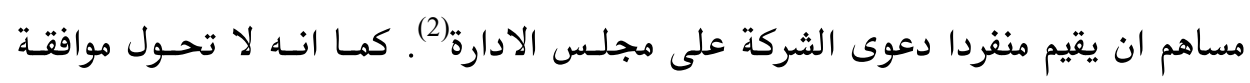
الهيئة العامة على ابراء رئيس واعضاء مجلس الادارة من هذه المسؤولية (3) لكي لا يفلت هئل

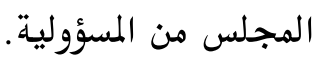

ان القانون الفرنسي قد نظم هذه الدعوى فللمساهمين ان يطالبوا بالتعويض عـن

كامل الضرر اللاحق بالشركة ويحكم بالتعويض للشركة(4) حيث حصر اسلوب التعويض

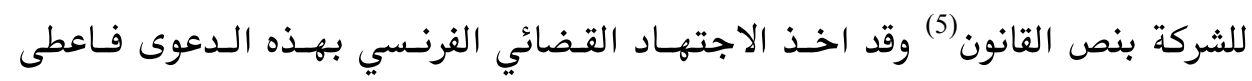
للمسساهم بمفـرده ولعسدد مسن المساهمين الـذين يعملـون مغترقـين ولنقابسة المساهمين او تجمعاتهم المعترف لهم بالشخصية الحق في مباشرة دعوى الشركة لحماية حق الـشريك

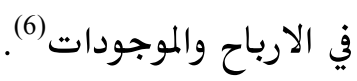

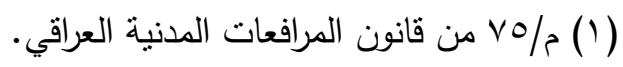
(Y)

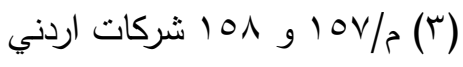

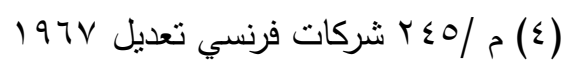

(0) الموقف الاردني يعلق التعويض بموضوع المطالبة اما ضرره الثخصي اوني اون ان يكون

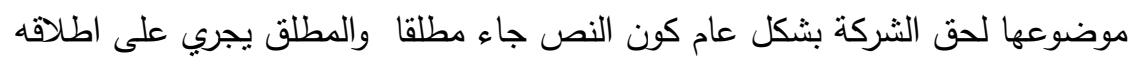

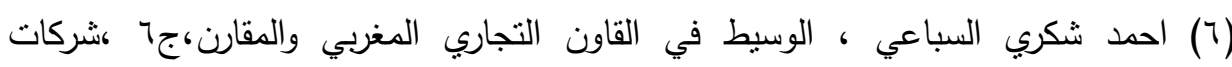

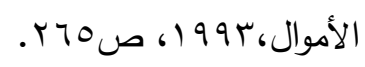




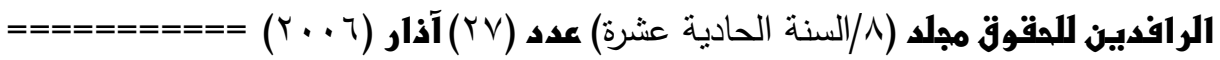

ان اقامة دعوى الشركة من المساهم هي بالواقع دعويان في القانون الاولى يطالب بتعويضه عن الضرر الذي اصابه فضلاً عسن ضسرر الـشركة وكأنمـا عندما يطالب بـضرر الشركة كأنه وكيل قانوني خاصة عندما ينص القانون على ذلك (1). ويسري على دعوى الشركة ما يسري على باقي دعاوى المسؤولية من حيث التقادم. فقد نص القانون الاردني (2) على انه لا تسمع دعوى المسؤولية بعد مرور خمسس سنوات على تاريخ اجتماع الهيئسة العامسة الـذي صـادقت فيـه علسى الميزاينـة السنوية الختامية للشركة في تلك السنة فيجب اقامة الدعوى قبل انقضاء مدة التقادم.

اما القانون الفرنسي (3) فيجعل دعـوى الـشركة والـدعوى الفرديـة ضـد مجلـس الادارة تنقض بمضي ثلاث سنوات تبتديء من تاريخ حدوث الضرر أومن تاريخ العلم به وبمضي عشر سنوات ان تعلق الامر بجريمة جنائية. والقـانون العراقي لم يـنص على مسدة التقـادم فلابـد مسن الرجسوع الى القواعـد

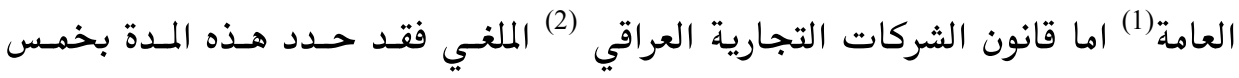

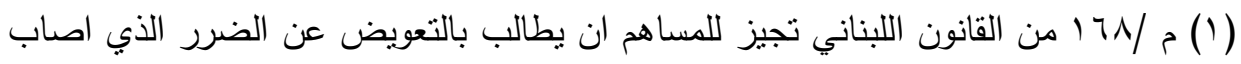

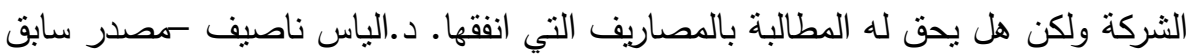


سنوات مسن تـاريخ انعقـاد الهيئسة العامسة الـتي ادى منهـا مجلـس الادارة حسسابا عـن

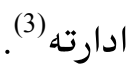

ان هذه الدعوى ذات طبيعة مزدوجة وهي ليست اصلية ولكنهـا تقـام في حالـة

عدم قيام الهيئة العامة باثارة هذه الدعوى وادعوا القانون العراقي ان ينظمنها الى جانب

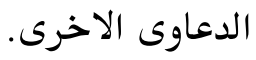

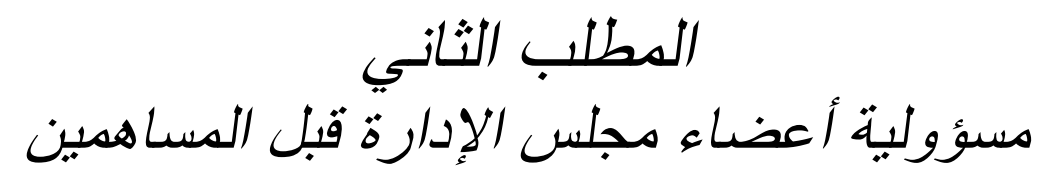

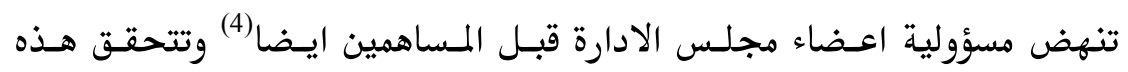

المسؤولية اذا صدر عنهم ما يشكل ضررا لاحد المساهمين كما لو قاموا بمناورات احتيالية وذلك بنشر وقائع كاذبة عن مركز الشركة المالي - حملت المساهم الى الاكتتـاب وشـرائه

(1) م/ r r r من القانون المدني - مدة تقادم العمل غير المشروع بانقضاء ثُلاث سنوات من

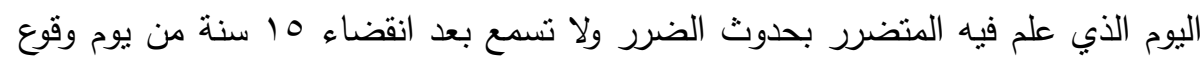

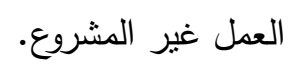

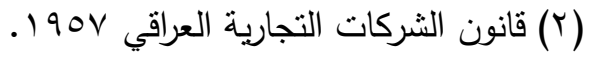

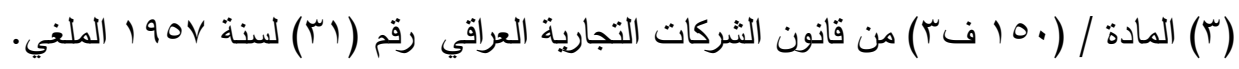

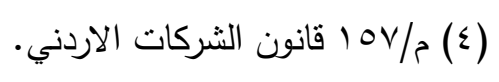




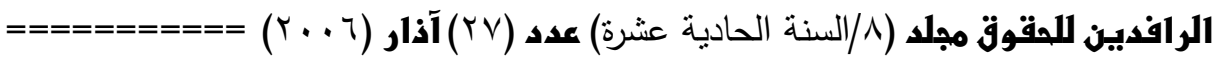

لاسهم الشركة بقيمة عالية ولو علم بحقيقة مركزها مـا أقدم على ذلـك. او قيسام احسد اعضاء المجلس او المجلس ككل بسلب احد المساهمين حصته من الارباح. ومسؤولية مجلس الادارة قبل المساهمين مسؤولية قانونيسة تخـضع في حكمهـا للقواعد العامة كون المساهم ليس له رابطة عقدية مع مجلس الادارة وانما يمثل من خلال الهيئة العامة فمسؤولية مجلس الادارة قبل المساهمين مسؤولية تقصيرية(1) سببها التقصير في الادارة فيسألون عن الخطأ اليسير او الجسيم (2) ويمكن المطالبة عـن انخفـاض قيمسة اسهم المساهم(3) ومن الشروط التي يجب ان تتوافر في هذه المسؤولية ان يكون مساهما في

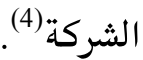

ان الضرر الناشيء عن اخطاء مجلس الادارة قد يلحق احد المساهمين شخـصيا ولا علاقة له في الشركة لذا سميت هذه الـدعوى (بالفرديسة) فهـي ترفـع باسـم المساهم للدطالبة بالتعويض عن الضرر الذي لحقه شخصيا(5) كالاحتيال في نشر وقائع كاذبة عن

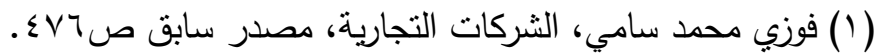

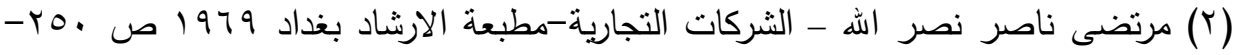
ص صוO.

(r) ويجوز القضاء المصري للمساهم مطالبة اعضاء مجلس الادارة بالقيمة الاسمية للاسهم التي انتراها اذا نقصت قيمتها بسبب سوء الادارة. قرار محكمة القاهرة الابتدائية في

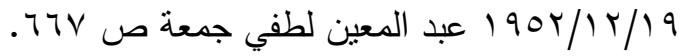

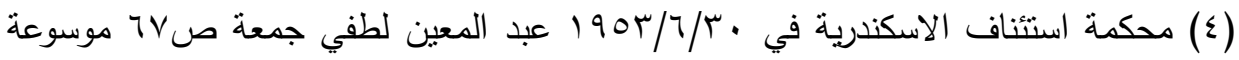

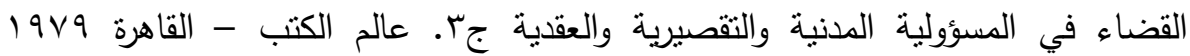
ص

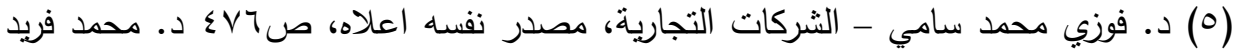

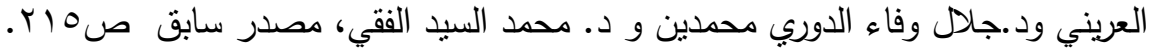


مركز الشركة لو علم بالحقيقة لما اكتتب او توزيـع اربـاح صسورية او سـلب حسصة احسد المساهمين من الارباح ويمكن ان يقيمها فرد او مجموعة من المساهمين (1). والمعيــار الـذي يميـز دعــوى المـسـاهم الــتي يقيمهــا للمطالبــة بتعويـضهـ عـن الـضرر الخــاص الـذي لحقـه عــن دعـوى الـشركة هــو الـضرر الـذي لحسـق المساهم شخصيا.

ان القانون العراقي لم ينص على هذه الدعوى شانه في ذلك شأن بقية الدعاوى. ولذلك يمكن الرجوع الى القواعد العامسة للمطالبـة بـالتعويض عـن الـضرر الـذي يـصيب

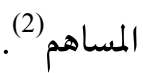
على ان يثبت ان هناك ضـررا اصـابه مسن جـراء خطـأ مجلس الادارة او احـد اعضائه ويقيم العلاقة السببيية بـين الخطـأ والـضرر ولقاضسي الموضسوع تقـدير التعـويض (3) المناسب وما دامت هذه الدعوى شخصية فلا شأن للهيئة العامة بذلك فلا تملك الـصلح او التنازل عن هذا الحق ولا يعتد بالابراء اذا صدر عن الهيئة العامة مع جهل المساهمين بما ارتكبه مجلس الادارة من خطأ جسيم كأن يصعب عليهم ان يعلموا به وقـت انعقـاد الهيئة العامة للمصادقة عليه(4) ونادى بعض الفقه باعتبار قرارات الهيئة العامسة بـابراء

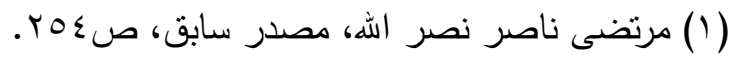

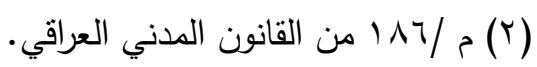

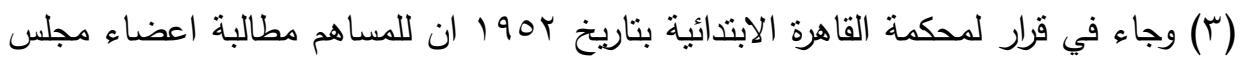
الادارة بالقيمة الاسمية للاسهم التي اشتراها اذا انخفضت قيمتها بسبب سوء الادئ الادارة اشتار اليها مصطفى كمال طه - القانون التجاري، ص اله، دار الجامعة الجديد للنشر الاسكندرية 


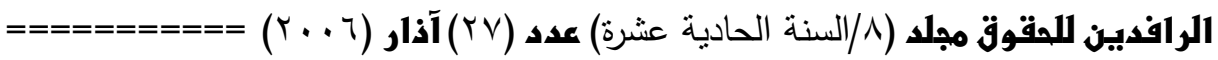

ذمة اعضاء مجلس الادارة واخلاء مسؤوليتهم عن الادارة باطلة(1) وبالنسبة الى التعـويض فان دعوى المساهم التي يرفعها باسمه الشخصي فيها يحصر طلبه بجـزء مسن التعويض الذي يعود اليه(2) ويشترط القضاء على المساهم الـذي يطعسن في ادارة مجلس الادارة ان يحدد العمليات المطعون فيها وليس له طلب تعيين خبير لفحسص حالـة الـركة بقـصد الكشف عن وقائع يتخذونها اساسا لدعواهم(3) وفي قرار قضائي (4) فـالابراء مسن الـدين عمل تبرعي محض لا يملكه مجلس الادارة في الـشركة المساهمة الا بالـشروط القانونيسة ولصحة الابراء يتطلب صدور قرار من مجلس الادارة بنـاء على تـرخيص مسن الهيئسة العامة فلا يملك التنازل عنه مجلس الادارة لاحد اعـضاء المجلس وان اعطي صـلاحية اجراء التسويات والصلح والتنازل عن التأمينات الا انه لا يخول له سـلطة التنـازل عـن الديون لتعارض ذلك مع الغرض الذي قامت الشركة من اجله واذا تعدد المسؤولون عـن الخطأ فتكون المسؤولية تضامنية بحكم القانون(5) والعكس صحيح اذا تسبب في الخطـأ احد الاعضاء فيلزم لوحدة التعويض ولا يلزم بالتعويض من اعترض على القرار الخطأ من

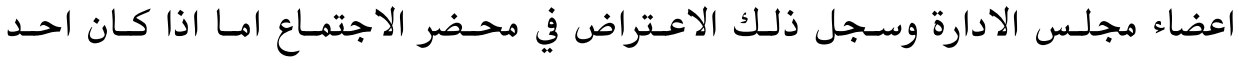

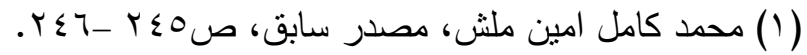

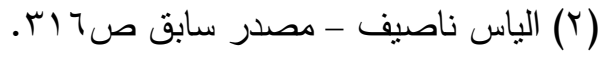
(r) قرار محكمة الاستئناف المختلطة في 10

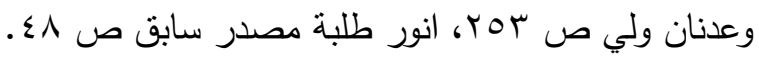

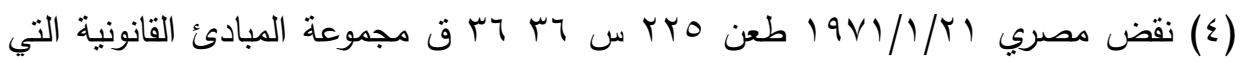

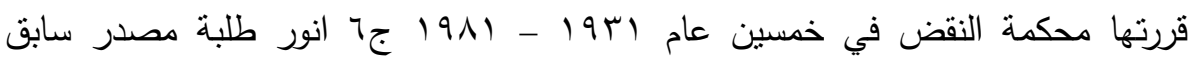

$$
\begin{aligned}
& \text { الاسكندرية ص^ی }
\end{aligned}
$$

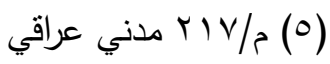


الاعضاء غائبا فـان الغيـاب لوحسده لا يعفيـه مـن المسؤولية الا اذا كـان الغيـاب بعـذر

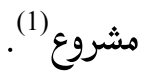

اما عن موقف القانون الاردني فقد عالجته المادة 109 من قانون الشركات والتي

تنص ان رئيس واعضاء مجلس الشركة المساهمة العامة مسؤولون تجـاه الغسير بالتـضامن

والتكافل وتجاه المساهمين عن تقصيرهم او اهمالهم في ادارة الشركة(2).

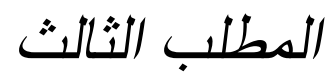

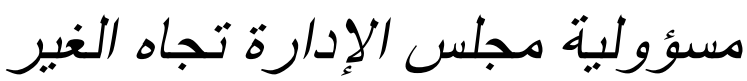

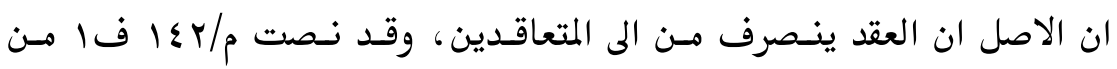

القانون المدني العراقي (3) على "انه ينصرف اثر العقد الى المتعاقدين" اما الغسير فلابسد ان

يكون احد شخصين (4).

اولهما شخص يدخل اصلا في عداد من يمثل المتعاقد في العقد من خلف عـام او

خلف خاص او دائن ولكن اثر العقد لا ينصرف اليه في حالات استثنائية.

وثانيهما شخص اجنبي عن العقد تماما فلا تقوم مسؤولية رئيس واعضاء مجلس

الادارة قبل الشركة فقط بل تقوم مسؤوليتهم قبل الغير(5) ايضا غـير ان قـانون الـشركات

(1) د. الياس ناصيف -، مصدر سابق، صب آب.

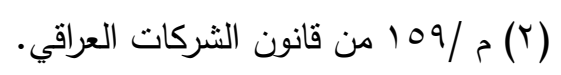

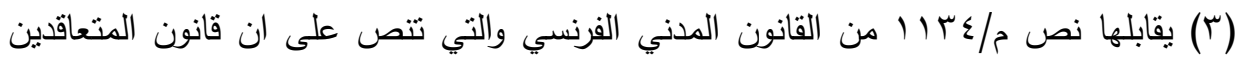

الخاص هو رابطة لا ينتفع بها ولا يضار الا اطرافها.

(ع) د. جاسم لفتة سلمان العبودي الموقف القانوني من قاعدة عدم جواز انتفاع الغير بالعقد

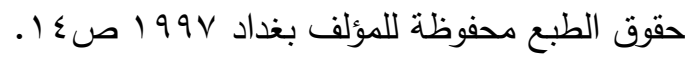

(0) المقصود بالغير هو كل شخص طبيعي او اعتباري ذي علاقة باعضاء مجلس الادارة عدا

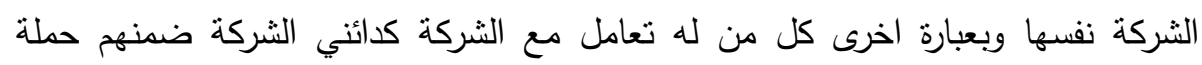




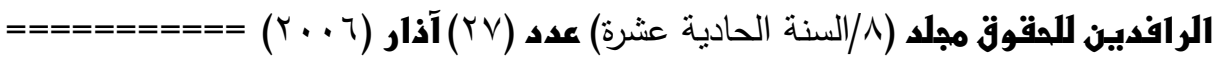

العراقي لم يقرر صراحة مثل هذا الامر بل قرر مسؤولية مجلس الادارة قبل الهيئة العامة

للشركة (1)

فاساس مسؤولية اعضاء مجلس الادارة قبل الغير هو الخطأ ومسن ثـم فـان هـذه

المسؤولية تخضع لحكم القواعد العامة المقررة في القانون المدني.

وتتحقق هذه المسؤولية(2) اذ اصدر عن اعـضاء مجلـس الادارة مـا يـشكل ضـررا

باحد الدائنين كما لو ارتكب اعضاء مجلس الادارة خطأ ادى الى خـسارة الـشركة لجـزء من رأسمالها الذي يعد الضمان لدائنيها فيمكن للغير ان يرفع دعوى المسؤولية على كـل

من :

1. الشركة عندما يكون الخطأ الواقع من اعـضاء مجلس الادارة هـو خطـأ في ادارة

الشركة.

r. كما يمكن للغير ان يرفع دعوى على عضو او اعضاء مجلس الادارة الـذين صدر

عنهم الخطأ اذا كان جسيما او مذطويا على غش او مخالفـة صـريحة للقـانون او

لنظام الشركة او عقدها.

والفقه متفق على ان مسؤولية اعـضاء مجلـس الادارة قبـل الغسير هي مسؤولية

تقصيرية(3) وذلك لعدم وجود اية رابطة عقدية بين اعـضاء مجلس الادارة والغسير اذ ان

سندات القرض وفي مقدمة الاغيار المساهمون في الثركة د. اكرم ياملكي مصدر سابق

ص

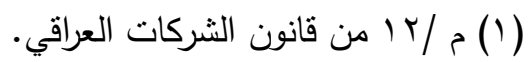

(Y) د. محمد فريد العريني و د. جلال وفاء البدري محدين ود.محمد السيد الفقي - مصدر

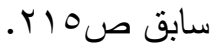

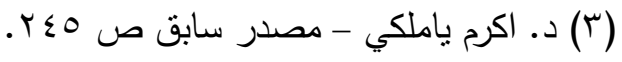


التصرفات الـتي يبرمهـا اعـضاء مجلس الادارة تنـصرف الى الـشركة ولسيس الى اعـضاء المجلس وهذه احدى نتائج تمتع الشركة بالشخصية المعنويسة اذ يترتـب علسى اكتساب هذه الشخصية ان يصبح للشركة وجودها القـانوني المتميـز عسن وجـود ونسشاط الـشركاء أو(المساهمين) وتخضع للاحكام القانونية الخاصة بها والتي تختلف تماما عسن الاحكسام التي يخضع لها المساهمون (1). وعليه يستطيع الغير (الدائن في مثالنا اعـلاه) اقامسة دعـوى الـشركة والـدعوى الشخصية كذلك بسبب اخطائهم التي الحقت به ضررا اذا كان جسيما او منطويـا على غش او مخالفة صريحة للقانون ليس استنادا الى عقد (2) يـرتبط بـه عـضو مجلس الادارة بالدائنين ولكن استنادا الى القواعد العامة (للمسؤولية التقصيرية). ويستطيع الغير كذلك اقامة الدعوى غير المباشرة(3) على اعـضاء مجلس الادارة بسبب اخطائهم التي الحقت به ضررا وهذه الدعوى ليست في الواقع الا استعمالا لحقوق مدينه او الحلول محل مدينه وهي الشركة التي اهملت في استعمال حقوقها الا انه يمكن الاحتجاج تجاه الغير بكل الدفوع التي يستطيع اعضاء مجلس الادارة الدفع بهـا تجـاه الشركة في حالة اقامة الدعوى غير المباشرة عليهم(4).

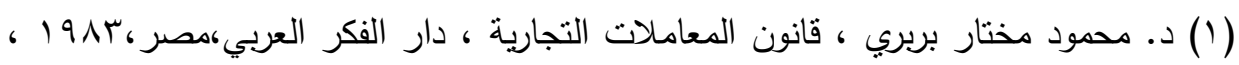
ص ع .1.

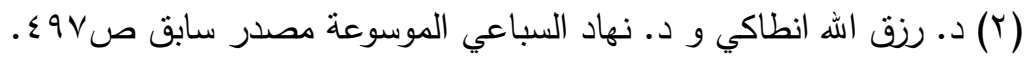

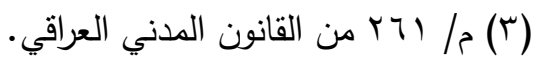

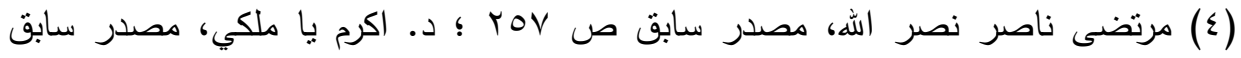
صع $ז$. 


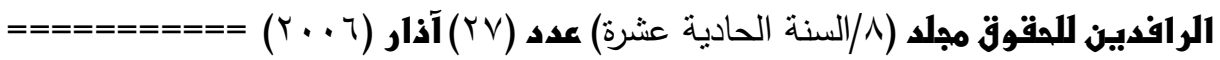

اما القانون الاردني (1) فقد نص على توضيح مسؤولية الـشركة عسن اعمـال رئسيس واعضاء مجلس ادارتها تجاه الغير حسن النية الذي يتعامل مع الشركة وللشركة الرجـوع عليه بقيمة التعويض عن الضرر الذي لحق بها وذلك بغض النظر عن أي قيد يرد في نظام الشركة او عقد تأسيسها - واعطى للغير ميـزة قانونيـة اخـرى بـان افـترض الغسير الـذي يتعامل مع الشركة اعتباره حسن النية ما لم يثبت غير ذلك على انه لا يلـزم ذلك الغسير بالتحقق من وجـود أي قيسد على صـلاحيات مجلـس الادارة ومسدير الـشركة او في الـزام الشركة بموجب عقدها او في نظامها وهذا الالتزام تجاه الغير هـو تطبيـق لنظريـة الوضـع الظاهر فالغير ليس ملزما بـان يتحقـق مسن وجـود قيـود علسى صـلاحيات مجلس الادارة والقاعدة ان الغير الذي تعامل مع الشركة يعتبر حسن النية الا اذا أثبت عكس ذلك(2). أن القانون الاردني قد اشار بشكل واضح وصريح الى مسؤولية اعضاء مجلس الادارة تجاه الغير فاخطاء مجلس الادارة الـتي تسبب ضسرا للغسير توجـب مسؤولية مجلس الادارة التقصيرية(3) ومن الاعمال التي توجب مسؤولية مجلس الادارة، قيامه بعمل مسن اعمال المنافسة غير المشروعة تلحق ضررا بالغير او تعاقده مع الغير حسن النية متجــاوزا السلطات الممنوحة له او امتناعه عن القيام باعمال يجب عليه القيام بها(4) وممـا تجـدر الاشارة اليه انه اذا وقع الخطأ من عضو معين فانه يتحمل المسؤولية عـن ذلـك الخطـأ دون الاخرين فالمسؤولية كمبدأ عام شخـصية وامـا اذا كـان الخطـأ مستركا مسن اعـضاء

$$
\text { (1) (107) من من قانون الثركات الاردني. }
$$

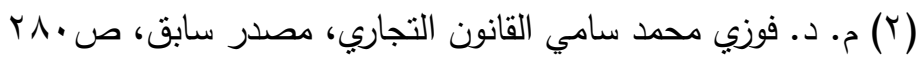

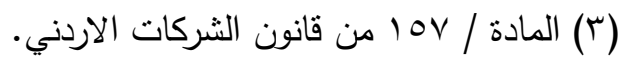

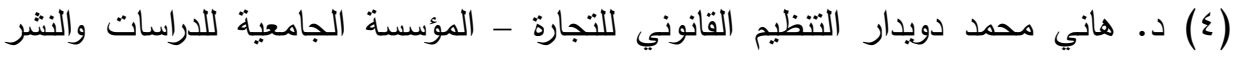

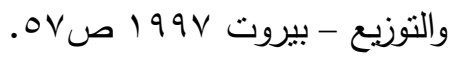


المجلس فانهم يتحملون المسؤولية بالتضامن على ان لا تشمل هـذه المسؤولية أي عـضو

اثبت اعتراضه خطيا في محضر الاجتماع على القرار الذي تضمن المخالفة او الخطأ (1). وعودا على بدء يجوز للغسير المتـضرر ان يرفـع دعـوى المسؤولية مباشـرة على مجلس الادارة او احد اعضائه شريطة ان يثبت خطأهم ويثبت وجود علاقة سببية بـين ما لحق به من ضرر وتلك التصرفات الناجمة عن المجلس. واساس هذه الدعوى هو الفعل الـضار ويظهـر ذلك جليـا بــص المـادة (ه9 إ) شركات حيث توجب مسؤولية مجلس الادارة او احد اعضائه التقـصيرية اذا ظهـر عنـد التصفية ان العجز كان بسبب اخطائهم في ادارة الشركة. كما يجوز ذلك للغير أيضا ان يرفع دعوى المسؤولية على الشركة وعلى اعـضاء مجلس ادارتها معا اذا اثبت له انهما متفقـان مسن التهـرب مسن المسؤولية وترفع هـذه الدعوى عادة من الدائن على المدين الذي ينوي الاضـرار بـهـ(2) ونجــد ان رفـع الـدعوى المشتركة على الشركة وعلى اعضاء مجلس ادارتها مبررة في ان موجـودات الـشركة اكثر

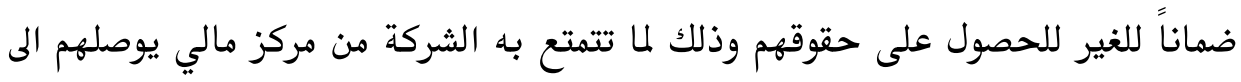
حقوقهم وما رفع الدعوى هذه الا ضمانة ثانية اذا عجزت الشركة عن الوفاء لاي سـبب كان فضلاً عن ان هذه الدعوى تحول دون حسدوث اتفـاق بـين الـشركة ومجلس الادارة (1) د. فوزي محمد سامي - الثركات التجارية - مصدر سابق ص صلع؟، د. لطيف جبر كوماني - الوجيز في شرح قانون الثركات الاردني مصدر سابق صیرسا : ومن الفقه من

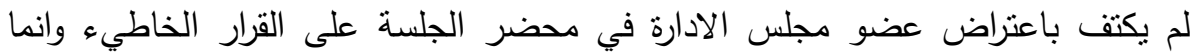

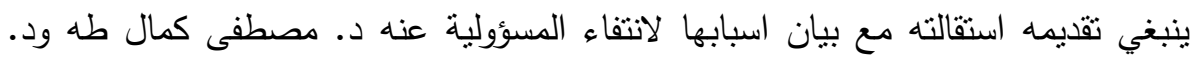

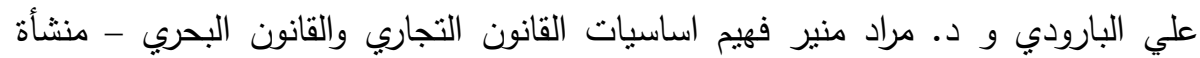

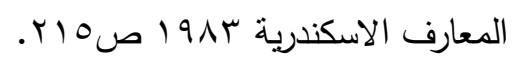

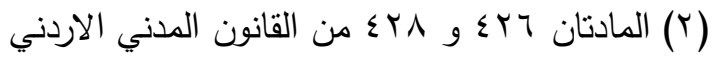




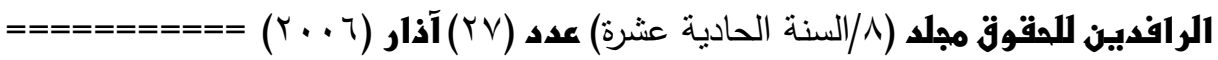

للتهــرب مــن المـسؤولية. ولكــن الـسؤال الـذذي لابــد مسـن الاجابــة عنــهـ هــو : ما حكم الشرط القاضي باعفاء رئيس واعضاء مجلس الادارة من المسؤولية سـواء ورد هـذا الشرط في نظام الشركة او عقدها؟ لم يتضمن قانون الشركات العراقي نصاً صريحاً يقضي ببطلان مثل هذا الـشرط كما هو عليه الحال في ظل قانون الشركات التجاريـة الملغسى عليسه فيجـب الرجـوع الى القواعد العامة المقررة في القانون المدني حيث نصت م/ههب فس على انه "يقع باطلا كل شرط يقضي بالاعفاء من المسؤولية المترتبة على العمل غير المشروع ومن ثم يقع باطلا كل شرط يقضي باعفاء اعضاء مجلس الادارة مسن المسؤولية المترتبـة على افعـالهم الـضارة تطبيقا لحكم هذه القاعدة العامة. ولكن من الناحية العملية من الصعوبة تصور ورود شرط الاعفاء في عقد تأسسيس الشركة لان قانون الشركات قد حدد بشكل دقيق البيانات التي يجب ان يتضمنها عقد الشركة(1) وهذه البيانات هي بيانات الزامية ذات طابع تنظيمسي يجـب اسـتيفاؤها والا رفض المسجل طلب التأسيس (2). اما القانون الفرنسي(3) فقد نص على انه يسال اعضاء مجلس الادارة شخصيا او على وجه التضامن حسب الحالات تجاه الشركة وتجاه الغير كما يرتكبونه من مخالفات للمقتضيات القانونية المطبقة على الشركات وخرقهم للنظـام الاساسي او اخطساء الادارة فهـي مسؤولية تقـصيرية، وقـد توسعت محكمسة الـنقض الفرنسية بـالقول ان احكـام

$$
\text { (1) م/ (1) ما من قانون الثركات العراقي. }
$$

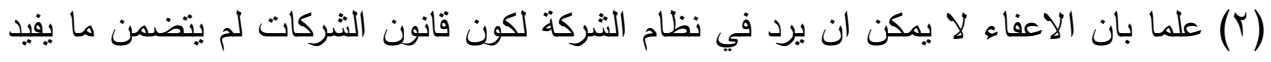

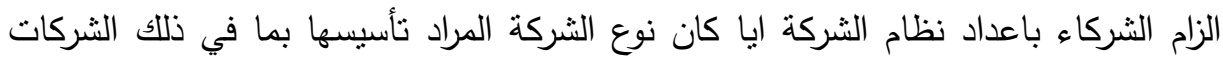

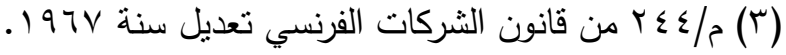


المسؤولية التقصيرية(1) في النظام العام وان اساس الدعوى ارتكاب اخطاء تقصيرية لتعاقد الشركة المدنية من الباطن مع شركة لتنفيذ العمل ولكن الاخيرة اضاعت مسودات الصور فقد قررت محكمة استئناف باريس المسؤولية على اساس ارتكاب خطأ تقصيري مسع ان

هذه الشركة المقصرة طالبت باقامة مسؤوليتها على اساس عقدي (2).

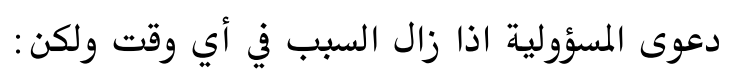

وعموما تنقضي (3)

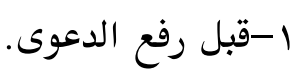

r-او قبل اليوم الذي تقضى فيه المحكمة ابتدائيا. ب- او خلال الاجل المحدد ولتدارك اسباب البطلان.

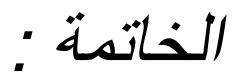

بعد الانتهاء مسن البحـث في موضسوع مسؤولية مجلس ادارة الـشركة المساهمة الخاصة في كل من القانون العراقي وبعض القوانين المقارنة توصلنا الى النتائج والتوصيات التالية : أولا: النتائج

ان القانون العراقي لم يتطرق الى ايراد نصوص تنظم اهم مسألة الا وهي مسؤلية اعضاء مجلس الادارة وانما احالها الى القواعد العامة واقتصر في قـانون الشركات على

(1) Cass com 17 fer 1987.

مشار اليها لدى د. صبري حمد خاطر - الغير عن العقد، الدار العلمية الدولية، ودار الثقافة

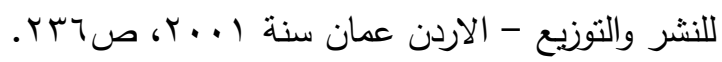

( ) Cass cir 8 Mars 1988

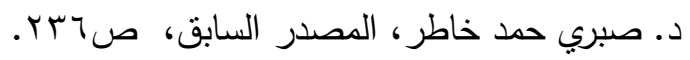

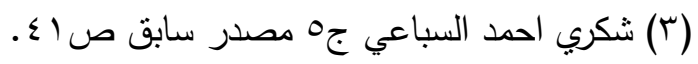




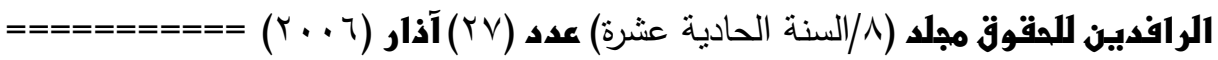

تذظيم هذه المسؤولية بموجب مادة واحدة تخص الطلب مسن عـضو مجلـس الادارة بـذل العناية المطلوبة من الشخص المعتاد في حين نظم القانون الفرنسي والاردني هذه المسؤولية فضلاً عن الدعاوى المتعلقة بها وحماية الغير حسن النية ومدى التزام الشركة بتـصرفات الاعضاء وشرط الابراء من قبل الهيئة العامة وكون المسؤولية تـضامنية او غـير تـضامنية واسباب تحقق المسؤولية وحالاتها. ثانيا. التوصيات

ان ايراد نص واحد في قانون الـشركات العراقي لمعالجـة موضسوع مهـم يتعلـق بمسؤولية مجلس الادارة لم نجده كافياً وهو الخاص ببذل العناية المطلوبة فادعو المـشرع الى النظر فيما يأتي : ا- مدى التزام الشركة مقابل تصرفات اعضاء مجلس الادارة. وحكم تجــاوز سـلطاتهم وابراء الهيئة العامة.

r- النص على حماية الغير حسـن النيـة الـذي يتعامـل دون ان يعلـم بتجــاوز اعـضاء مجلس الادارة حدود اختصاصاتهم. ب- تضمين قانون الشركات نصاً صريحاً في حكم المسؤولية التضامنية. ع- الذص على اسباب تحقق المسؤولية وحالاتها وتنظيم دعاواها.

\section{- المصادر \\ اولا: الكتب العربية}

ا ـ ـ د. ابو زيـد رضـوان - الـشركات التجاريـة في القـانون المـصري والمقـارن دار الفكـر

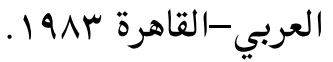


r. احمد ابراهيم البسام - الشركات التجارية في القانون العراقي مطبعة العاني - بغداد $.197 V$

r. د. احمد شكري السباعي - الوسيط في القانون التجاري المغربي والمقارن جף شركات

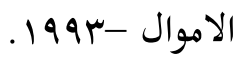

ع. احمد شكري السباعي - الوسيط في القانون التجاري المغربي والمقارن جه بو 199. ه. احمد سمير ابو شادي - مجموعة القواعد القانونية التي قرتهـا محكمسة الـنقض الدائرة المدنية في خمسة سنوات 1971977 - 197 - وزارة الثقافـة المؤسسة المـصرية العامة للتأليف والنشر - دار الكاتب العربي للطباعة والنشر. T. ادور عيد - الشركات التجارية - مطبعة النجوى- بيروت • 19V. V. د. اكرم ياملكي - الوجيز في شرح القـانون التجـاري العراقي الـشركات التجاريـة

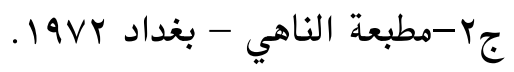
^. . د. اكرم ياملكي ود. فائق الشماع - القانون التجاري وزارة التعليم العسالي والبحـث

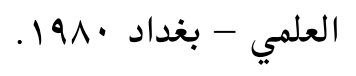

9 ه. الياس ناصيف - الكامل في قانون التجارة - الشركات التجارية جr منشورات البحر

$$
\text { المتوسط وعويدات - بيروت - باريس r 1919. }
$$

• ا. انور طلبة - مجموعة المباديء القانونية التي قرتها محكمة النقض المصرية - دار

$$
\text { المطبوعات الجامعية الجزء الخامس. }
$$

11 . د. باسم محمد صالح ود. عدنان احمد ولي العزاوي - القانون التجاري الشركات

$$
\text { التجارية - بيت الحكمة - بغداد } 91919 .
$$

r ا. د.جاسم لفتة سلمان العبودي - الموقف القانوني مسن قاعسدة عسدم جـواز انتفـاع الغير بالعقد - حقوق الطبع محفوظة للمؤلف بغداد 199V. 


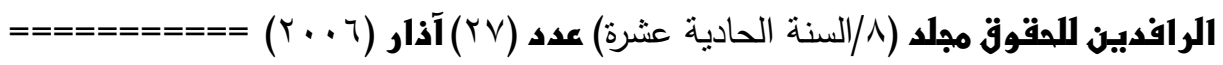

سا . د. حسني المصري - القانون التجاري وشركات القطاع الخاص - الكتاب الثـاني .1917 bصا م، مصر ع ا. د. رزق الله انطاكي و د. نهاد السباعي - موسوعة الحقوق التجاريسة والـشركات

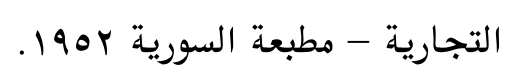

ه . د. رزق الله انطاكي و د. نهاد السباعي - الوجيز في الحقوق التجاريسة والبريسة ، ط؛ - مطبعة جامعة دمشق 1909.

ا ـ د.رياض الحلبي و د.احمد الجعبري، رشيد حمود رشاد العامر سالم الشريف محاسبة الشركات دار ضياء للنشر والتوزيع، عمان طا سنة .... . . IV. رمزي احمد ماضي - المباديء القانونية الصادرة عن محكمة التمييز الاردنية طا. 11. زياد رمضان - اساسيات في الادارة المالية - دار الصفاء للنشر والتوزيـع عمـان -

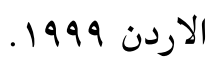

9 1. د. سليمان محمد الطماوي - مباديء علم الادارة العامة طV - مطبعة عين شمس مصر - 1919V

• ب. د. سـعيد يحيـى - الـوجيز في القـانون التجــاري - المكتـب العربـي الحـديث

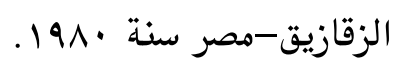

اY. د. سميحة القليوبي - الشركات التجارية - دار النهضة العربية س^و19. r.r. شكري حبيب شكري وميشيل ميكالا - شركات الاشخاص والاموال علما وعمـلا - مطبعة البروكاشيا - الاسكندرية ه191 . سr. ضياء شيت خطاب - الوجيز في شرح قانون المرافعات المدنية - بغداد سV91 . ع r. عباس مرزوق فليح - الاكتتاب في رأس المال الشركة المساهمة مكتبـة دار الثقافـة للنشر والتوزيع - الاردن 1991. 
هr. د. عبد الرزاق السنهوري الوسيط في القانون المدني جه. جr. عبد المعين لطفي جمعة -موسوعة القضاء في المسؤولية المدنية التقصيرية والعقديسة الكتاب الاول - جه الناشر عالم الكتب القاهرة 19V9. rV الفقه والقضاء - المدينة - الحديثة للطباعة القاهرة 19^^.

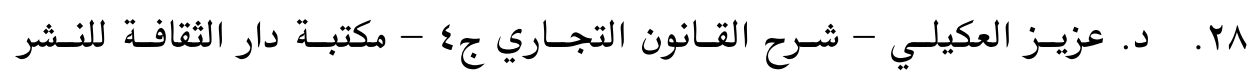

$$
\text { والتوزيع - عمان - الاردن سنة } 1991 .
$$

q. . د. علي جمـال الـدين عـوض - القـانون التجـاري دار النهـضة العربيـة القـاهرة $.197 \pi$

•r. علي العريف - شرح القانون التجاري المصري - مطبعة مخيمر القاهرة 1900. اس. عليان الشريف -مسطفى حسين سـلمان -رشـاد العطـار -القـانون التجـاري مباديء ومفاهيم -دار المسيرة للنشر والتوزيع والطباعة - الاردن سنة ....... rr. عليان الشريف - وفائق شفير وريـاض الحلـبي ومحمسد الباشـا مبـاديء القـانون التجاري طا -دار المسيرة للنشر والتوزيع والطباعة عمان ........ سب. د. فوزي محمد سامي - الشركات التجارية الاحكام العامـة والخاصـة - دراسـة مقارنة - مكتبة دار الثقافة، عمان 1999. ع ז. فوزي محمد سامي شرح القانون التجاري - الشركات التجارية الجزء ؟ - مكتبة دار الثقافة للنشر والتوزيع عمان - بيروت 199V. هـ. ـامل عبد الحسين البلداوي - الشركات التجاريسة مسن القـانون العراقي مطـابع وزارة التعليم العالي - الموصل • 199.

جس. مرتضى ناصر نصر الله - الشركات التجارية - مطبعة الارشاد بغداد 1979. 


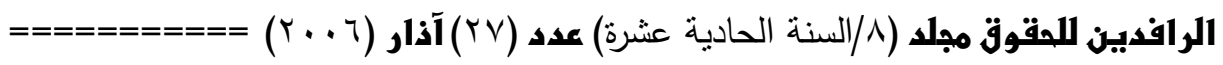

V. . ـ ـ. محمد شوقي شاهين - الشركات المشتركة طبعها واحكامها في القانون المصري والمقارن بيروت سنة طبع ·

^م. د. محمد فريد العريني و د. جلال وفاء البدري محمدين ود. محمد السيد الفقي ، مبادئ القانون التجاري ، دار الجامعة الجديدة للنشر ، الاسكندرية، مسصر،

$.199 r$

هץ. د. محمد كامل امين ملش بك ، الشركات ، مطابع دار الكتاب العربي ، مسصر $.190 \mathrm{~V} 6$

• ع. ـ د. محمد خليل المحمسوري - حمايسة اقليسة المساهمين او الـشركاء مسن الـشركة المساهمة الخصوصية والشركة ذات المسؤولية المحدودة - دراسة مقارنة - مطبعة

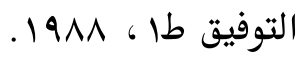

اء. ـ د. مسصفى كمـال وصـفي ، مسؤولية مجلس ادارة الـشركة المساهمة ، مسصر، .1901

ץء. مصطفى كمال طه - القانون التجاري - دار الجامعة الجديدة مصر •199. سع. مصطفى كمال طه ود. علي البـارودي و د. مـراد مـنير فهـيم اساسـيات القـانون التجاري والقانون البحري - منشأة المعارف الاسكندرية سه91 .

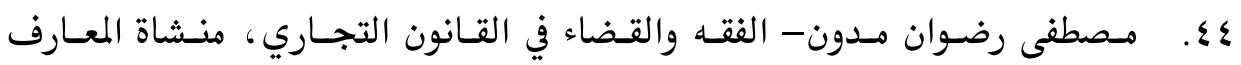
الاسكندرية.

ـ ـ. محمـود سمسير شـرقاوي - الـشركات التجاريسة في القـانون المسصري دار النهـضة

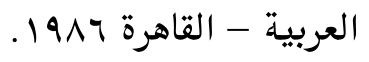

جـ. محمود مختار احمد بربري - قـانون المعـاملات التجاريسة -دار الفكـر العربسي مصر 191VV 
\&V

.1971

^^ـ. موفق حسن رضا - قانون الشركات اهدافه واسسه ومضامينه - منششورات مركز

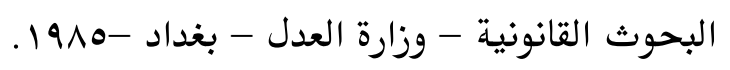

9ء. د. نوري طالباني وكامل عبد الحسين البلداوي وهاشم الجزائري القانون التجاري

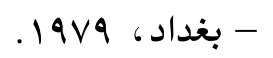

•ه. د. هاني محمد دويدار - التنظيم القانوني التجاري (المؤسسة الجامعية للدارسات

$$
\begin{aligned}
& \text { والنشر والتوزيع بيروت 199V } \\
& \text { ثانياً: الرسائل الجامعية }
\end{aligned}
$$

ا ـ. د. عمار نـاجي الـصالحي - مسؤولية مؤسسي الـشركة المساهمة الخاصـة رسـالة

$$
\text { ماجستير مقدمة الى جامعة بغداد كانون الثاني ...... }
$$

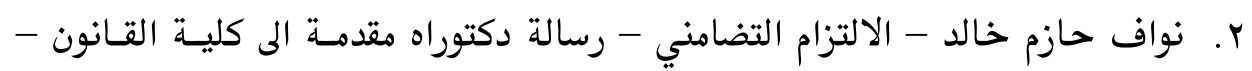

$$
\text { ثالثاً: البحوث والدراسات الموصل } 1999 .
$$

ا. ـ د. ابو زيد رضوان رضوان - مفهوم الشخصية المعنوية بين الحقيقة والخيـال بحـث

$$
\text { مقدم الى مجلة العلوم القانونية والاقتصادية ع ا مصر ·19V. }
$$

r. د. د. حسين يوسف غنايم - مسؤولية الشركة عن اعمـال المسير في مواجهته الغسير -

بحث منشور في المجلة العربية للفقه والقضاء تصدرها الامانة الفنيـة لمجلس وزراء

$$
\text { العدل العرب العدد (11) نيسان ـ199. }
$$




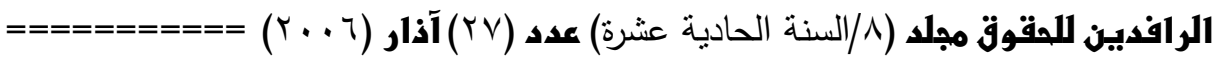

r. د. حسين يوسف غنايم -قانون الشركات التجارية في دولة الامارات العربية المتحدة بحث منشور في مجلة الشريعة والقـانون تـصدرها كليسة الـشريعة والقـانون جامعـة الامارات العربية المتحدة العدد ال - نيسان ra9ر.

ع. محمد سليمان الاحمد وهيثم المصاروة - المسؤولية التضاممية مجلة نقابة المحامين -

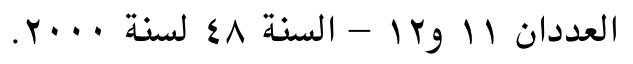

ه. محمد صالح بك، توحيد القوانين ومصادرها،الـشركة المساهمة تأسيسسها وتركيبهـا

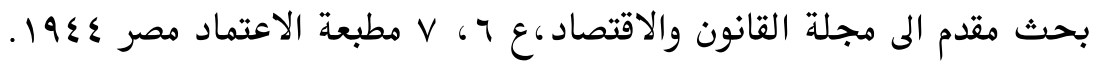
T. محمد علي يوسف - اثر مبدأ سلطات الارادة في تكـوين الـشركان المساهمة بحسث مقدم الى مجلة العدالة العدد الاول السنة الثانية - العراق سنة ........ V. نعوم سيوفي -مسؤولية اعضاء مجلس الادارة، بحث مقدم الى مجلة القـضاء العراقي

$$
\begin{aligned}
& \text { العدد الاول •197. } \\
& \text { رابعاً: القوانين }
\end{aligned}
$$

الدستور العراقي، الصادر في 1 تموز • •19V وتعديلاته.

1. قانون الشركات العراقي ذو الرقم إب لسنة I99V.

r. قانون الشركات الاردني ذو الرقم بr لسنة I99V.

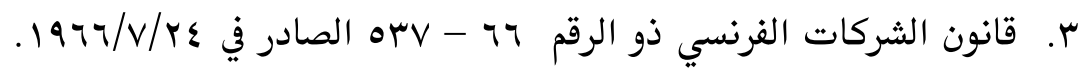

ع. قانون الشركات المصري ذو الرقم ؟ لسنة 1991.

ه. قانون الشركات الاردني ذو الرقم rا لسنة £ 197.

ج. قانون الشركات العراقي ذو الرقم جس لسنة س^و19.

V. القانون المدني العراقي ذو الرقم ؛ لسنة 1901.

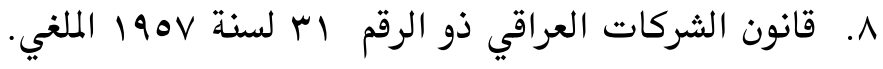




$$
\begin{aligned}
& 9 \text { 9. قانون المرافعات المدنية العراقي ذو الرقم سی لسنة } 1979 \text { المعدل. } \\
& \text { • . . قانون المرافعات الاردني ذو الرقم عب لسنة 1911. } \\
& \text { خامساً: المصادر الأجنبية : }
\end{aligned}
$$

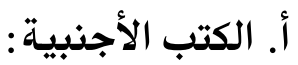

1- Maurice Cazian, Alain Viandier, DROIT DES SOCIE TES, Editions Litecm 1992.

2- $\quad$ Code des commerce, Dalloz, Edition, 2001.

3- Jacques elgo: Droit des societes, Edition, Dalloz, Parise, 1998.

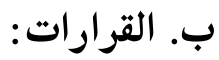

1. Cass com. 17, fer. 1987. 2.Cass cir. 8, mars. 1988. فهرست 